\title{
Analysis of The Representations in Turkish Middle School Science Textbooks from 2002 to 2017
}

\author{
Hakan Akcay \\ Department of Mathematics and Science Education, Yildiz Technical University, Istanbul, \\ Turkey ORCID: 0000-0003-0307-661X
}

Hasan Ozgur Kapici*

Department of Mathematics and Science Education, Yildiz Technical University, Istanbul, Turkey ORCID: 0000-0001-7473-1584

\author{
Behiye Akcay \\ Department of Mathematics and Science Education, Istanbul University-Cerrahpasa, \\ Istanbul, Turkey ORCID: 0000-0002-0546-8759
}

\begin{tabular}{ll}
\hline \hline Article history & Textbooks are one of the primary sources for students to obtain \\
Received: & knowledge, so they should present accurate knowledge through textual \\
15.04.2020 & and visual representations. The goal of the current study is to examine the \\
Received in revised form: & representations in middle school science textbooks based on the diagram \\
11.06 .2020 & coding scheme to find out a general picture of how representations used \\
& in the science textbooks over the fifteen years. The sample consists of \\
Accepted: & 6247 representations from twelve middle school science textbooks (four \\
24.06 .2020 & each of sixth, seventh, and eighth grades) from 2002 to 2017. Content \\
Key words: & analysis was used to analyze the representations in textbooks, which were \\
\hline multiple representations; & gathered by document analysis. The representations were evaluated \\
visuals; & concerning the combination of two main diagram coding schemes. \\
images; & Findings showed that iconic representations are prevalent in middle \\
science textbooks & school science textbooks. There are limited charts, graphs and augmented \\
& reality representations in the science textbooks. Furthermore, there are \\
& more male representations than female ones, representations are mostly \\
& indexed in the main texts, and captions are mainly problematic in middle \\
& school science textbooks. The findings based on the two diagrams coding \\
& scheme are mainly coherent with each other. Science textbooks should \\
encourage students to interpret and translate between different & representations to enable them accurate knowledge.
\end{tabular}

\section{Introduction}

Textbooks are important instructional materials from which students gain knowledge during their schooling years by providing representations, examples, and exercises (Devetak \& Vogrinc, 2013; Ilhan, Seker, \& Kapici, 2015; Liu \& Khine, 2016; Nakiboğlu, 2009; Postigo

\footnotetext{
*Correspondency: $\underline{\text { hokapici@yildiz.edu.tr }}$
} 
\& López-Manjón, 2019; van den Ham \& Heinze, 2018). Furthermore, they are not only an important tool for enhancing students' conceptual knowledge but also have crucial impacts on students' cognitive and metacognitive skills (Liu \& Khine, 2016). Therefore, textbooks have received great attention from scholars in science education (Abd-El-Khalick et al., 2017; Gkitzia, Salta, \& Tzougraki 2011; Kılıç \& Sert, 2015; Papageorgiou, Amariotakis, \& Spiliotopoulou, 2017; Upahi \& Ramnarain, 2019).

The knowledge presented in textbooks is important because if they contradict scientific knowledge then students may misinterpret the concepts (Cheng \& Gilbert, 2014). Textbooks facilitate the learning process by enabling students to connect real-world entities, theories, and phenomena (Ahtineva, 2005). This connection is usually done through diagrammatic representations (Liu \& Khine, 2016). That's why, if they are used well, then they can be an efficient instructional material to augment teaching and learning (Nyachwaya \& Wood, 2014).

In the current research, it was focused on the textual and pictorial representations used in the middle school science textbooks because students assess visual images as a part of the written text rather than independent way from the text (Pinto \& Ametller, 2002). In particular, it was examined the representations in terms of several criteria such as graphical types, gender representation, indexing, captioning, formality and function of a visual image.

\section{Theoretical framework}

Theories related to multiple representations are mainly based on assumptions about knowledge processing and limitations of working memory due to the human mind structure (Opfermann, Schmeck, \& Fischer, 2017). Opfermann and colleagues (2017) explain two fundamental theories on learning with multiple representations as Multimedia Learning Theory, and DeFT (Design, Functions, Tasks) Framework. The current research was also developed based on both of the theories.

\section{Multimedia learning}

The cognitive theory of multimedia learning was developed by Mayer (1997, 1999, 2003). The theory mainly generated from dual coding theory (Paivio, 1986), the model of working memory (Baddeley, 1992) and generative theory (Wittrock, 1989). In the theory of dual coding approach developed by Paivio (1986), he explains that human cognition has separate information processing systems for handling simultaneously with the information which can involve verbal and visual representations. Working memory can only deal with a limited amount of information in an information processing system at a certain time (Baddeley, 1992). Furthermore, meaningful learning occurs when learners actively engaging cognitive processes by paying attention to relevant words and visuals, mentally organizing them into appropriate verbal and visual representations, and mentally associating these representations with each other and with previous knowledge (Mayer, 2003; Wittrock, 1989). To ensure meaningful learning, learners' cognitive systems should be stimulated by two stimuli encoded in verbal and visual systems (Paivio, 1986). In other words, presenting text and images together provide more advantages for students' understanding than presenting them alone. When these two representation types are presented together, interpretation of ambiguous representation (e.g., text alone) may be constrained by the specific representation (e.g., an image) independently of issues of familiarity or experience (Ainsworth, 1999, p.140). 
In the textbook-based learning environments, the external stimulus can be printed words and representations, which are perceived by eyes. Then the learner selects relevant parts of the printed words and the representations for further processing. Besides, the learner can transform some parts of the printed words and even some of the visuals into verbal representations. The next process is organizing an appropriate mental representation based on verbal data and appropriate mental representation based on visual data. And the next step is integrating verbal and visual representations and with prior knowledge. Consequently, if the three processes (selecting, organizing, and integrating) occurs for verbal and visual representations successfully, then meaningful learning takes place (Mayer, 2003).

\section{DeFT (Design, Functions, Tasks) framework}

The framework is mainly developed by Ainsworth (2006) and can be assumed as an extensive form of multimedia learning because DeFT framework not only includes (written or spoken) words and corresponding pictures but also involves photos, diagrams, tables, graphs, concept maps, and other written materials (i.e. notes taken during learning). Ainsworth (1999, 2006) claims that multiple representations have three fundamental functions, which are complementary roles, constrain the interpretation and constructing deeper understanding. The complementary role means that different representations (e.g. table and graph) show the same information or each of them conveys unique information but complementary to each other (Ainsworth, 2014; Opfermann et al., 2017). For example, presenting data on the table and showing the data on the graph may facilitate learning because each of these representations supports different cognitive processes (Opfermann et al., 2017). The second function of multiple representations is constraining interpretation that is constraining each other's interpretation possibilities when being presented together (Opfermann et al., 2017, p.10). For instance, spoken words can be unclear in some cases, so providing a picture can make more sense. Ainsworth (2006) explains this as when these two representations (spoken words and pictures) are being presented together, interpretation of the spoken words may be constrained due to its unclearness by the second representation (picture). The last main function of multiple representations is constructing a deeper understanding. This means that learners can connect the different representation types and so gain knowledge that would be difficult to gather from just one representation alone (Ainsowrth, 2006). Tsui and Treagust (2013) summarize the DeFT framework developed by Ainsworth $(1999,2006)$ as they support meaningful learning i) when they are designed to support different cognitive processes or convey complementary knowledge, ii) constraining interpretations protect the learners to make misinterpretations, iii) enhancing meaningful understanding via abstraction, extension and relation (for more see Ainsworth, 1999, 2006).

\section{The roles of textbooks in the learning process}

Textbooks have been commonly used in classes. For example, $77 \%$ of secondary science or mathematics teachers use published textbooks in the US (Banilower et al., 2013) or $86 \%$ of teachers in Germany use mathematics textbooks in their classes (Mullis et al., 2012). In other words, textbooks are used at all levels of education as a primary organizer of content knowledge (Chiappetta \& Fillman, 2007). One of the views about textbooks' role in the learning process is that when students read the text in a textbook, their prior knowledge interacts with the representations (visual image and text) in the textbooks which impact students' learning and recalling the knowledge (Bransford, Brown, \& Cocking, 2000). One of the advantages of the textbooks is they involve visual images, explanatory drawings, and diagrams as an illustration of texts (van der Meij \& de Jong, 2006). The crucial point is 
encouraging students to translate between different representation types and levels. In this way, the cognitive load on the working memory of a student will diminish; thus, learning will be more easily (e.g., Chittleborough, Treagust, \& Mocerino, 2005; Gabel, 1993).

Students' abilities to interpret and produce representations is also one of the factors which have an impact on their scores in standardized tests such as PISA and TIMMS (Anagnostopoulou, Hatzinikita, \& Chritidou, 2012; Hatzinikita, Dimopoulos, \& Christidou, 2008). For example, PISA 2015 results showed that Turkish students ranked 55th out of 73 countries for scientific literacy level (Taş et al., 2016). Similarly, TIMMS 2015 results also showed that Turkish fourth-grade students ranked 35th out of 47 countries and Turkish eighth-grade students ranked 21st out of 39 countries (Y1ldırım et al., 2016). Textbooks can be also one of the possible agents for these outcomes. For instance, Hatzinikita and colleagues (2008) state that the differences between PISA test items and the Greek school science textbooks in terms of textual and graphical modes may be a reason for the low success of Greek students in the test. Similarly, Anagnostopoulou and colleagues (2012) compared the visual items about biological systems in 7th and 9th-grade biology textbooks in Greece and the visual images used in the PISA test. They concluded that there are tensions between visual images in the PISA test and the biology textbooks used in Greece concerning the type of visual representations and the functional role of graphs. Yeh and McTigue (2009) examined 985 test items that involve representation in state science tests from 14 states in the US. They concluded that to have successful students in standardized tests, students should be familiar with how to interpret and how to produce a visual representation. In other research, Geske and Geske (2010) advocate that when science textbooks have less narrative and more activities for students in Latvia, the students' science scores increased in TIMMS. Consequently, multiple representations in science textbooks have crucial impacts on students' achievement and conceptual learning.

Diagrams, illustrations, drawings, photographs, formulas, graphs, and tables are some main types of visual representations in science textbooks (Devetak \& Vogrinc, 2013; Lee, 2010) and there are many studies about visual representations in textbooks. The studies mainly have been focusing on two different aspects, one of which is the theoretical basis for the functions of representations on learners' meaningful understanding (Ainsworth, 1999, 2006) and the other one is the examination of visual representations used in textbooks (Papageorgiou, Amariotakis, \& Spiliotopoulou, 2017). Primary findings based on these studies reveal that whereas half of the page space in science textbooks is dedicated to visual images (Lee, 2010), most of those visual images are not related to content (Mayer, 1993). Another important result is that most of the representations are macroscopic ones (Lee, 2010), which are concrete and visible that can be seen by a naked eye (Johnstone, 1993). One of the recent textbook analyses was done by Liu and Khine (2016) on twenty primary students' textbooks used in the Kingdom of Bahrain. They reached that great amount of diagrams are used in the primary textbooks and most of these are iconic types. Demirdöğen (2017) examined the multiple representations used in four Turkish high school chemistry textbooks. She also reached that macroscopic representations are common in the high school chemistry textbooks. Furthermore, she concluded that the majority of the representations have proper captions and almost all of them are completely related to the texts. Similar research was done by Upahi and Ramnarain (2019) in the Nigerian chemistry textbooks. They found that symbolic representations such as equations, graphs, charts, and signs are the most common diagrammatic representations used in the chemistry textbooks. They also reached that although representations mainly related to the texts, there was no link in the texts to direct student's attention to the corresponding representation. Another research was done by Shebab 
and BouJaoude (2017) to evaluate the visual representations in seven secondary Lebanese chemistry textbooks. They concluded that macroscopic representations are the most widespread representation types in the chemistry textbooks. They also found that most of the representations had problematic or no captions. Similar studies were also done with middle school science textbooks. For example, Kapic1 and Savasci-Acikalin (2015) examined representations about the particulate nature of the matter in eight middle school science textbooks used in Turkey. They also reached that macroscopic representations were the most prevalent ones and more than half of the visuals had no caption.

\section{Importance of the study and research questions}

Textbooks are one of the rich sources for diagrammatic representations and mainly have three fundamental components, which are the general structure, visual materials, and text (Devetak \& Vogrinc, 2013). The general structure includes general information of the textbooks such as the number of pages and chapters. The other component is texts in the textbooks, which are also important because content knowledge is presented through it. Lastly, textbook illustrations constitute the visual aspect of textbooks. Textual and visual materials in the science textbooks have crucial roles in science teaching because inaccuracies in textbook illustrations and/or texts cause students' misconceptions (Kesidou \& Roseman, 2002). In related literature, the studies mainly examined the visuals related to a specific topic, especially in chemistry education. Yet, in the current research, all of the diagrammatic representations in 12 middle school science textbooks used in Turkey between 2002 and 2017 were evaluated. Examining thousands of diagrammatic representations in middle school science textbooks enabled us to reach abundant information about the usage of multiple representations in middle school science textbooks. In this light, the purpose of this research was to examine the images in sixth, seventh and eighth grades science textbooks in terms of the types, gender representation, degree of relatedness to texts, properties of captions, formalities and functions from 2002 to 2017 (2002, 2011, 2014, and 2017). Within this goal, the study was designed to answer the following research questions:

- How did the types of images in the middle school science textbooks change from 2002 to 2017 according to the grade levels?

- How did gender represented in the middle school science textbooks change from 2002 to 2017 according to grade levels?

- How did the degree of relationship between texts and images in middle school science textbooks change from 2002 to 2017 according to grade levels?

- How did the properties of the captions in the middle school science textbooks change from 2002 to 2017 according to the grade levels?

- How did the functions of the visuals in middle school science textbooks change from 2002 to 2017 according to the grade levels?

\section{Method}

The study is based on a qualitative research methodology. The data was gathered by a document analysis of the twelve middle school science textbooks used in Turkey from 2002 to 2017. The representations gathered from the science textbooks were analyzed by content analysis. 


\section{Sample}

The representations in the 12 middle school science textbooks used in Turkey between 2002 and 2017 were analyzed in the current research. The researchers considered two main criteria while choosing the middle school science textbooks: All textbooks must be approved by the Ministry of National Education (MoNE) and they must be widely used. Based on the considerations, four books from sixth grade, four books from seventh grade and four books from eighth grade were selected to examine (Appendix A).

\section{Instruments}

The representations in the middle school science textbooks were analyzed concerning the combination of two main diagram coding schemes. The first one was developed by Khine and Liu (2017) according to the Graphical Analysis Protocol designed by Slough, McTigue, Kim, and Jennings (2010). Four categories from the scheme, which are graphical types, gender, indexing and captioning involved in the scheme used for the current research. The second coding scheme, which is another basis for the coding scheme used for this research, is developed by Dimopoulos, Koulaidis, and Sklaveniti (2003). Two categories from the scheme, which are the formality of visual images and function of visual images, included in the scheme used for the current research. The coding scheme designed based on these categories is given in Table 1.

Table 1. Rubric for coding the categories.

\begin{tabular}{|c|c|c|c|c|c|c|c|c|c|c|c|c|c|c|c|c|}
\hline \multicolumn{4}{|c|}{ Graphical types } & \multicolumn{2}{|c|}{ Gender } & \multicolumn{2}{|c|}{ Indexing } & \multicolumn{2}{|c|}{ Captioning } & \multicolumn{3}{|c|}{$\begin{array}{l}\text { Formality } \\
\text { of visual } \\
\text { images }\end{array}$} & \multicolumn{4}{|c|}{$\begin{array}{l}\text { Function of visual } \\
\text { images }\end{array}$} \\
\hline 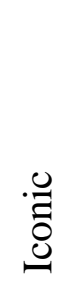 & 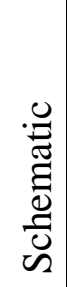 & 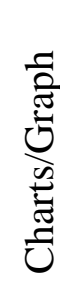 & 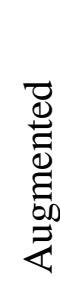 & $\underset{\frac{0}{\tilde{J}}}{\frac{0}{\mathbb{d}}}$ & $\sum_{\frac{0}{\pi}}^{\frac{0}{\Sigma}}$ & 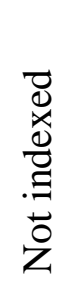 & 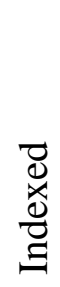 & 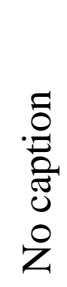 & 总 & 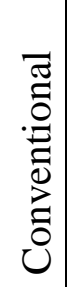 & 龸 & 鰙 & 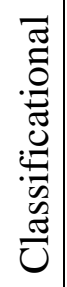 & 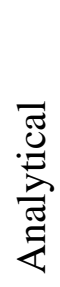 & 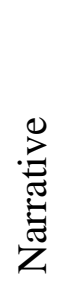 & 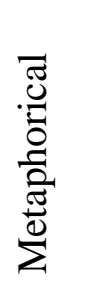 \\
\hline & & & & & & & & & & & & & & & & \\
\hline & & & & & & & & & & & & & & & & \\
\hline & & & & & & & & & & & & & & & & \\
\hline
\end{tabular}

Graphical types were divided into four categories. The first one is the iconic representations. They are the direct appearance of the objects being shown (Lee, 2010), such as photographs or drawings (Figure 1) (Hegarty et al., 1991). The second category is schematic representations, which represent abstract concepts by conserving the physical relationships of the main information (Liu \& Khine, 2016). A schematic representation of magnetic fields can be an example (Figure 2). The next category is charts and/or graphs that mainly involve numerical information such as line graphs, polar charts, and pie graphs (Figure 3) (Hegarty et al., 1991). Augmented reality was also used as another category, which was added to the original rubric by Liu and Khine (2016). The images created and designed multimedia technology considered under the category of augmented reality (Figure 4).

Gender representation was categorized as male and female. For the indexing category, if there is no link in the text related to the visual, then it was coded as not indexed. If the visual is 
mentioned in the text, then it was coded as indexed. Similarly, the visuals were analyzed based on captioning, which has two categories: no caption and captioned. No caption category includes any title or description under the visual (Figure 5). Captioned one has a title or description which is written under the representation (Figure 6).

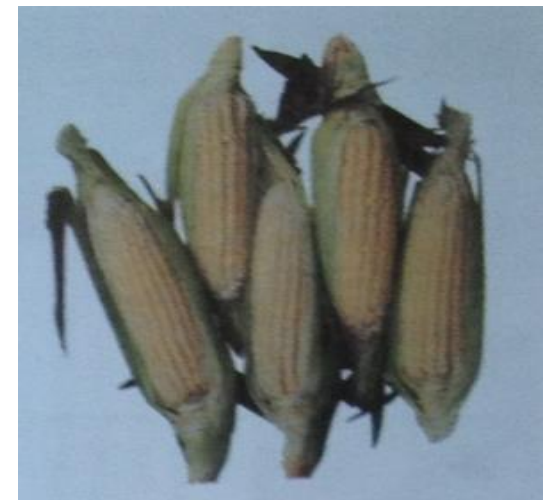

Figure 1. An iconic image of corns taken from $6^{\text {th }}$ grade science textbook (Güngör et al., 2002, p.40).

\begin{tabular}{|ll|}
\hline Tür & $2 \mathrm{n}$ \\
Kedi & $2 \times 19$ \\
Köpek & $2 \times 39$ \\
\hline Deniz yıldızı & $2 \times 47$ \\
At & $2 \times 32$ \\
Insan & $2 \times 23$ \\
Moli balığı & $2 \times 23$ \\
Soğan & $2 \times 8$ \\
Güvercin & $2 \times 8$ \\
\hline
\end{tabular}

Figure 3. A chart taken from $8^{\text {th }}$ grade science textbook (Çelik Koyuncu et al., 2002, p.112).

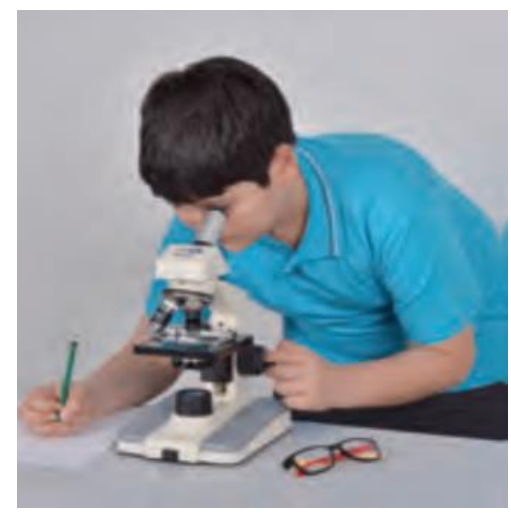

Figure 5. No caption of a student working on microscope taken from $7^{\text {th }}$ grade science textbook (Tuncel, 2017, p. 62).

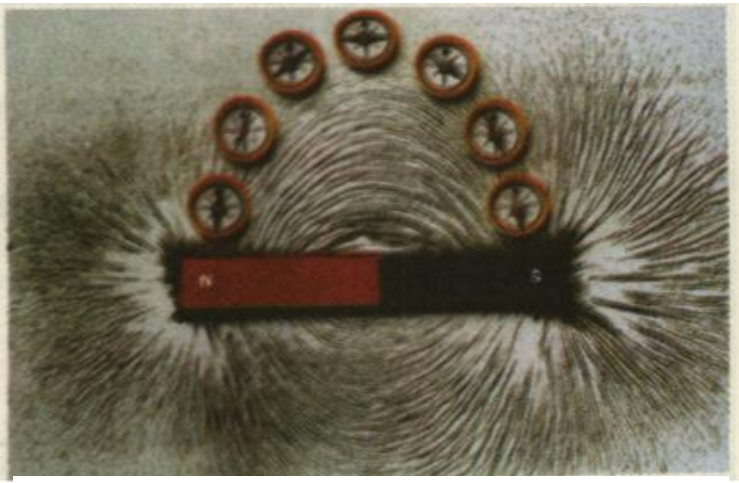

Figure 2. A schematic image of magnetic fields taken from $6^{\text {th }}$ grade textbook (Güngör et al., 2002, p.148).

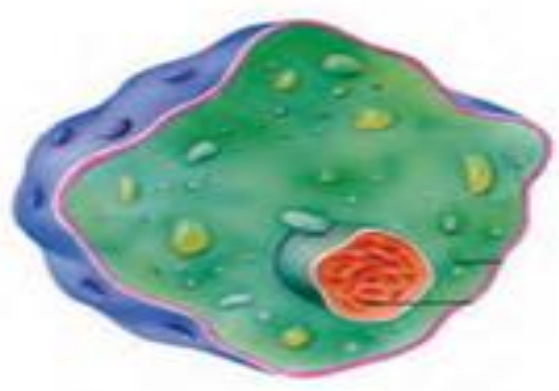

Figure 4. An augmented reality of animal cell taken from $7^{\text {th }}$ grade science textbooks (Tuncel, 2017, p. 16).

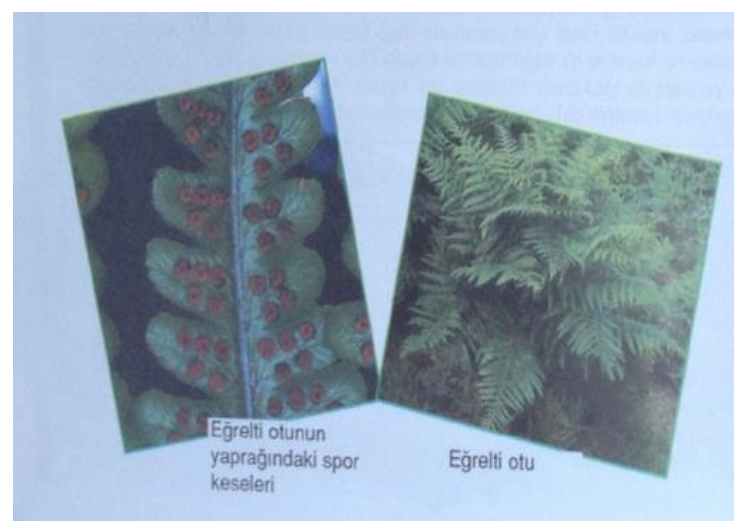

Figure 6. Captioned picture about fern taken from $6^{\text {th }}$ grade science textbook (Güngör et al., 2002, p. 42). 
The formality of visual images was analyzed in three categories. These are realistic images, conventional images, and hybrid images. Reality images represent the entities that can be perceived by a naked eye such as photographs and drawings (Figure 7) (Dimopoulos et al., 2003; Devetak \& Vogrinc, 2013). Conventional images represent reality in a codified way (Dimopoulos et al., 2003) such as diagrams, flowcharts, maps or graphs (Figure 8). Hybrid images are the ones that involve realistic and conventional images together in the same visual (Figure 9) (Dimopoulos et al., 2003).

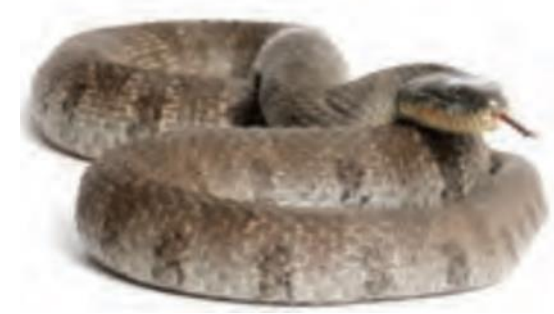

Figure 7. Realistic image of a snake taken form $7^{\text {th }}$ grade science textbook (Tuncel, 2017, p. 24).

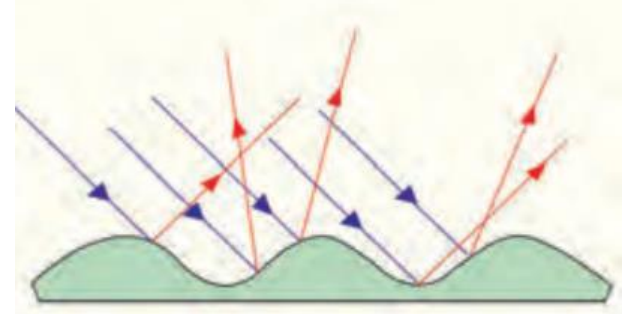

Figure 8. Conventional image of diffuse reflection taken from $7^{\text {th }}$ grade science textbook (Tuncel, 2017, p. 129).

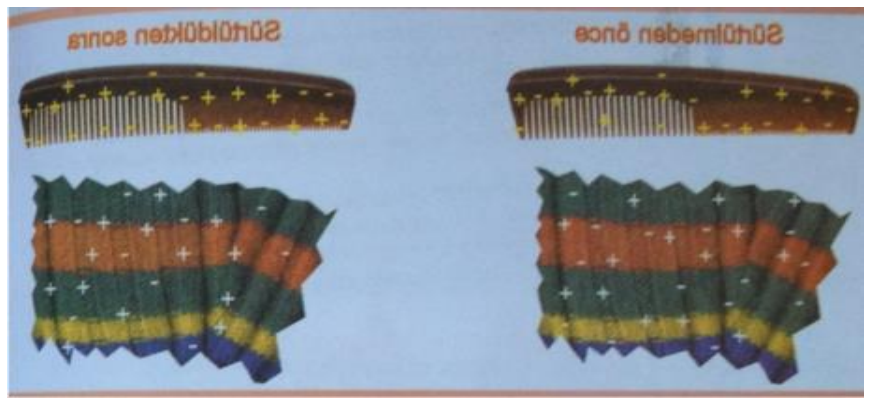

Figure 9. Hybrid image of static electric taken form $6^{\text {th }}$ grade science textbook (Güngör et al., 2002, p.110).

The representations were also examined concerning their functions in four categories: Classificational, analytical, narrative and metaphorical. Whereas classificational and analytical images emphasize powerful visual images in terms of the educational context, narrative and metaphorical images emphasize weak visual images. Classificational images present types of relationships between the things, places or people presented in taxonomy (Figure 10) (Dimopoulos et al., 2003). Analytical images represent the visual in terms of partwhole structure relationships (Figure 11) (Dimopoulos et al., 2003). Narrative images involve a vector (or arrow) either explicitly or imaginarily that shows the process of an action or event (Figure 12) (Dimopoulos et al., 2003) such as the carbon cycle. The last one is metaphorical images that represent the images harnessed with specific cultural symbols (Figure 13) (Dimopoulos et al., 2003). 


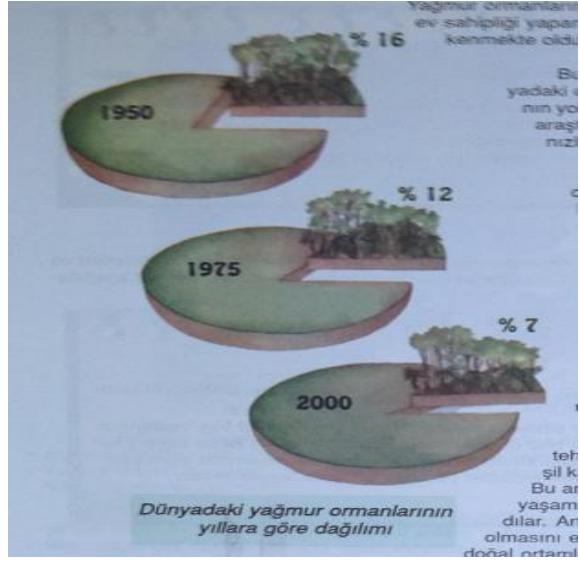

Figure 10. Classificational image of distribution of rain forests in the world according to years taken from $6^{\text {th }}$ grade science textbook (Güngör et al., 2002, p.46).

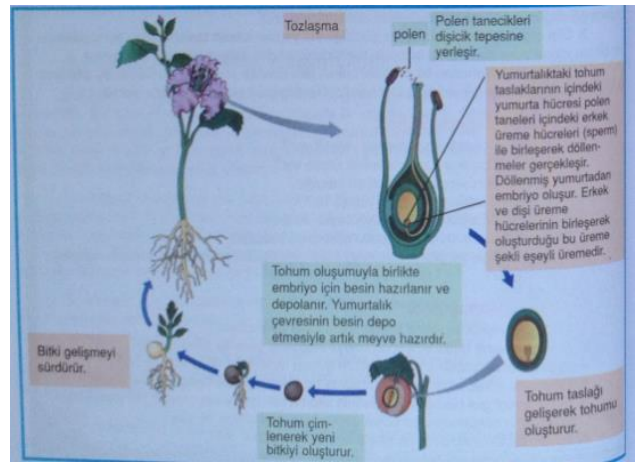

Figure 12. Narrative image for life cycle of a plant taken from $6^{\text {th }}$ grade science textbook (Güngör et al., 2002, p. 36).

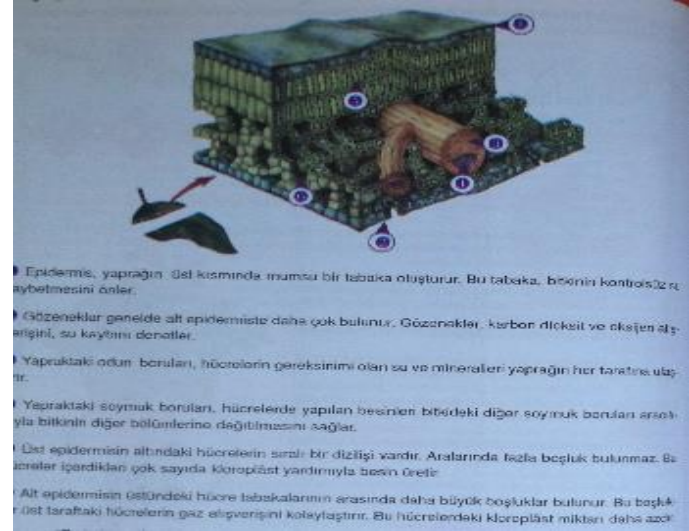

Figure 11. Analytical image of a leaf structure under the microscope taken from $6^{\text {th }}$ grade science textbook (Güngör et al. 2002, p. 32).

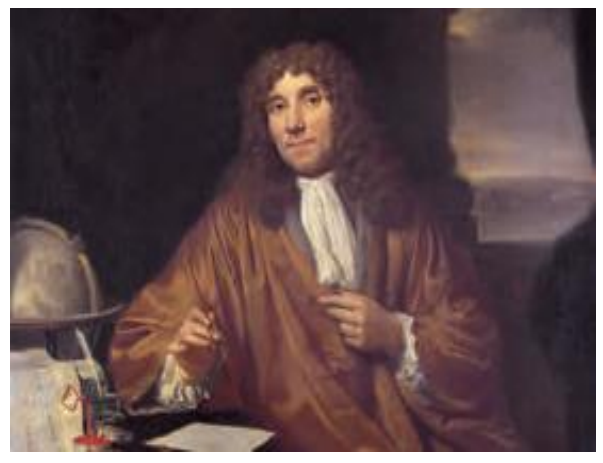

Figure 13. Metaphorical image of Antonie van Leeuwenhoek taken from $7^{\text {th }}$ grade science textbook

(Tuncel, 2017, p. 22).

In the next step, the reliability values for the research were calculated by Miles and Huberman's formula (Reliability $=$ consensus / consensus + disagreement). Three different researchers analyzed the $20 \%$ of representations for each category concerning the coding rubric independently. The inter-rater reliability coefficient for each category was given in Table 2. Agreement has been reached between researchers.

Table 2. Miles and Huberman's agreement percentage for each category.

\begin{tabular}{ll}
\hline Category & Miles and Huberman's agreement percentage \\
\hline Graphical Types & $79 \%$ \\
Gender & $81 \%$ \\
Indexing & $94 \%$ \\
Captioning & $91 \%$ \\
Formality of Visual Images & $83 \%$ \\
Function of Visual Images & $85 \%$ \\
\hline
\end{tabular}




\section{Findings}

The results for the total number of representations and the average number of representations per page were given in Table 3. Subsequently, the findings were presented to each category.

A total of 6247 representations (2078 visual images from sixth-grade science textbooks, 2472 visual images from seventh-grade science textbooks and 1697 visual images from eighthgrade science textbooks) from 2581 pages were collected. Findings revealed that whereas the seventh-grade science textbook, which was published in 2002, had many visual representations per page than others, the eighth-grade science textbook, which was published in 2017 , had the least number of representations per page.

Table 3. Number of the representations in the science textbooks.

\begin{tabular}{lllll}
\hline Grade & Year & $\begin{array}{l}\# \text { of Pages } \\
\text { sampled }\end{array}$ & $\begin{array}{l}\text { Total \# } \\
\text { representations }\end{array}$ & $\begin{array}{l}\text { of } \\
\text { representations per page }\end{array}$ \\
\hline 6th & 2002 & 171 & 414 & 2.42 \\
6th & 2011 & 258 & 735 & 2.84 \\
6th & 2014 & 176 & 309 & 1.75 \\
6th & 2017 & 226 & 620 & 2.74 \\
7th & 2002 & 159 & 507 & 3.18 \\
7th & 2012 & 239 & 658 & 2.75 \\
7th & 2014 & 243 & 547 & 2.25 \\
7th & 2017 & 254 & 760 & 2.99 \\
8th & 2002 & 156 & 448 & 2.87 \\
8th & 2011 & 259 & 527 & 2.03 \\
8th & 2015 & 258 & 439 & 1.70 \\
8th & 2017 & 182 & 283 & 1.55 \\
Overall 6 & & & 2078 & \\
Overall $7^{\text {th }}$ grade & & & 2472 & \\
Overall $8^{\text {th }}$ grade & & & 1697 & \\
\hline
\end{tabular}

Overall results showed that there are more representations per page on seventh-grade science textbooks (2.79 representations per page) than sixth and eighth-grade science textbooks. The total number of representations and the average number of representations per page were the lowest for the eighth-grade science textbooks (2.04 representations per page). There are 2.44 representations per page on the sixth-grade science textbooks.

\section{How did the types of images in the middle school science textbooks change from 2002 to 2017 according to the grade levels?}

The findings showed that an iconic type of representations has been mostly used in middle school science textbooks. It had the highest ratio (71.3\% iconic representations) for a total of four seventh grade science textbooks (Figure 14). It gradually decreased for sixthgrade science textbooks (69.6\% iconic representations) (see Figure 15) and had the lowest value (68.8\% iconic representations) for the eighth-grade science textbooks (Figure 16). The science textbooks, which were published in 2011 for sixth and eighth grades, and published in 2012 for seventh grade, involved more iconic representations than the others. The number of iconic representations in the science textbooks fluctuated from 2002 to 2017. 


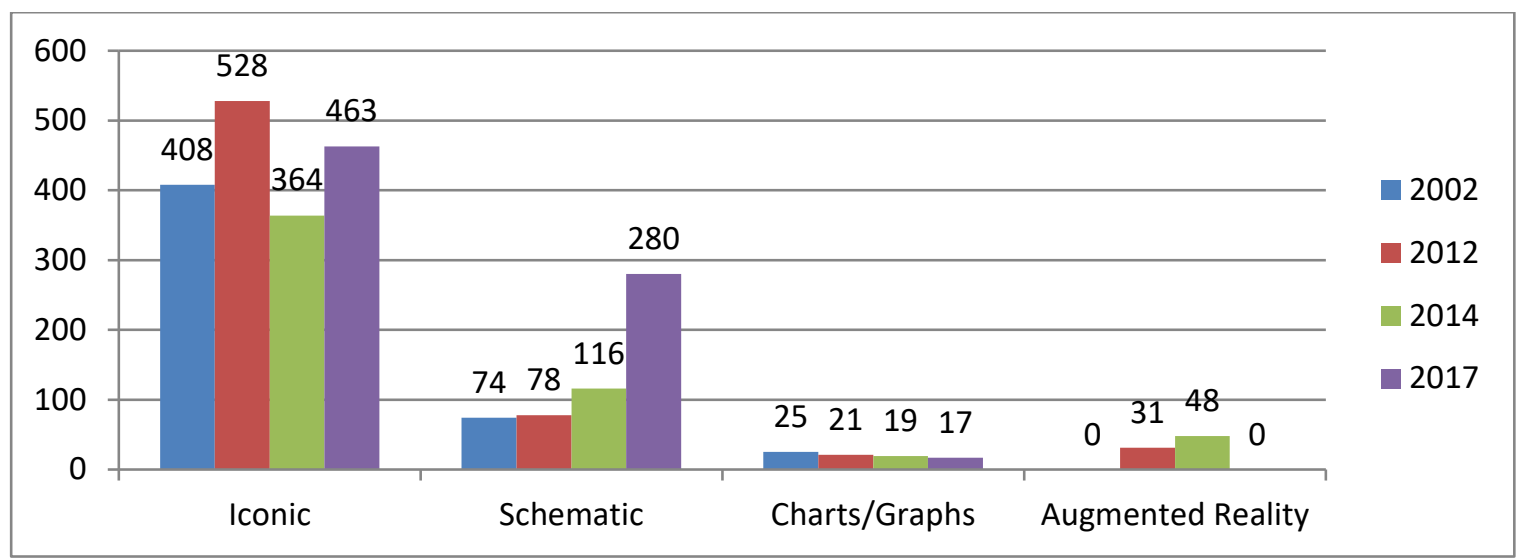

Figure 14. The seventh grade textbooks' analysis based on the graphical types.

Schematic representations also have been usually used in middle school science textbooks. The number of distribution of schematic representations was similar to iconic representations. It was at most for the seventh-grade science textbooks (22.1\% schematic representations) and at least for the eighth-grade science textbooks (15.9\% schematic representations). In a total of four sixth grade science textbooks, $20.6 \%$ of visuals were schematic representations. There is no certain conclusion about changes in the number of schematic representation in the science textbooks. Yet, the sixth and seventh-grade science textbooks published in 2017 included many more schematic representations than the ones published before.

Charts and graphs rarely involved in the science textbooks. Whereas the eighth-grade science textbooks included the highest ratio of charts and graphs (7.6\%), it was at the minimum level (3.3\%) for the seventh-grade science textbooks. The value for charts and graphs was $6.1 \%$ in all of the sixth-grade science textbooks.

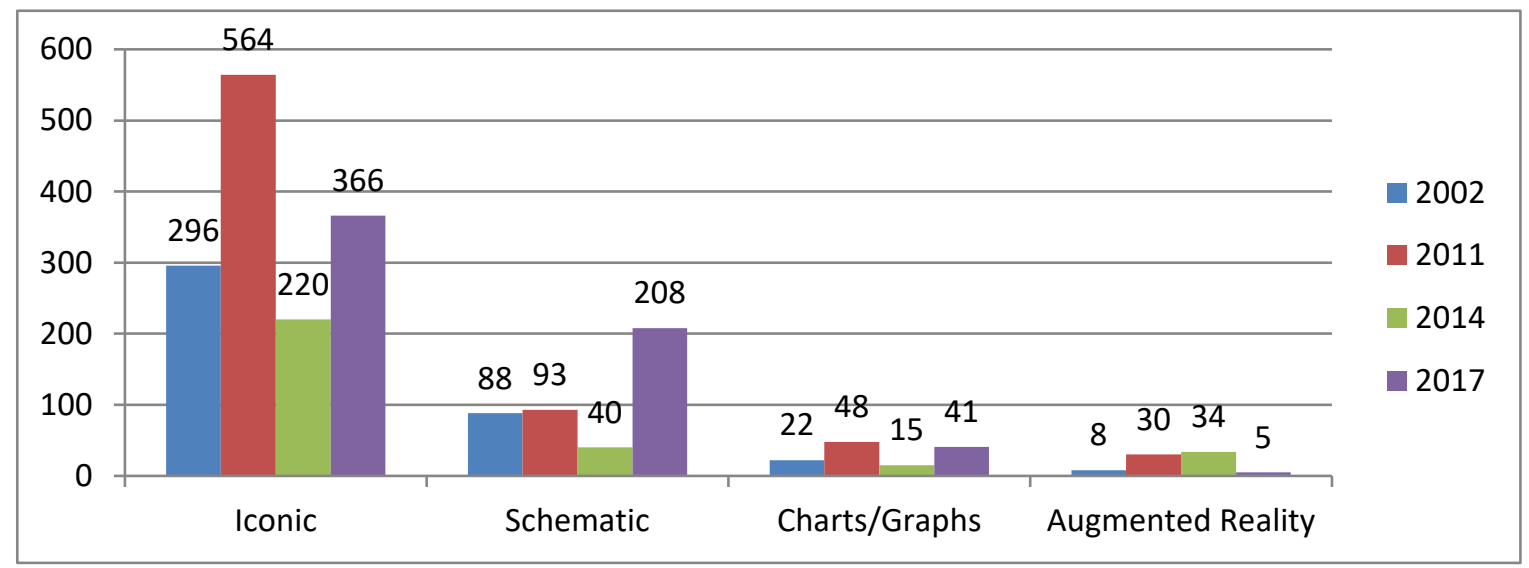

Figure 15. The sixth grade textbooks' analysis based on the graphical types.

The total number of augmented reality used in the science textbooks was similar to charts and graphs (337 charts and graphs used in all science textbooks and 287 augmented reality representations included in all science textbooks). It had the highest value for the eighth-grade science textbooks (7.7\% augmented reality) and had the lowest ratio $(3.2 \%)$ for the seventhgrade science textbooks. Only $3.7 \%$ of the visuals in all of the sixth-grade science textbooks were augmented reality representations. 


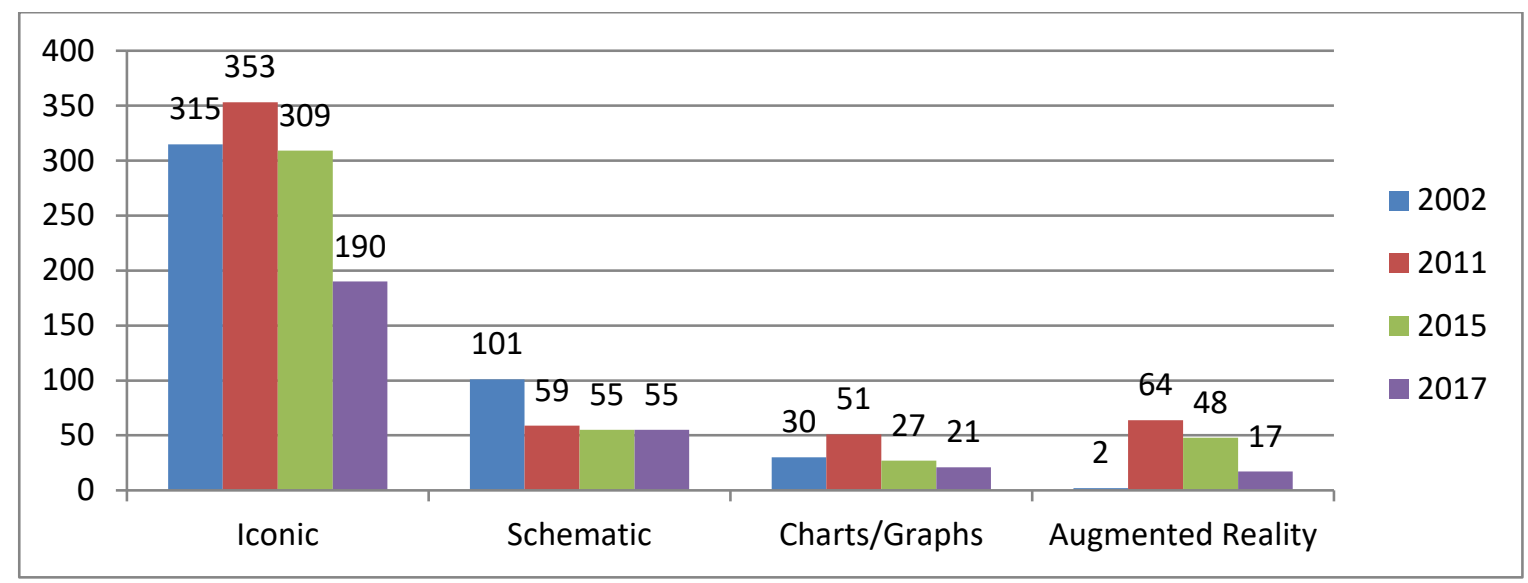

Figure 16. The eighth grade textbooks' analysis based on the graphical types.

\section{How did gender represented in the middle school science textbooks change from 2002} to 2017 according to grade levels?

The results showed that there were a total of 1137 gender representations (18.2\%) in all of the twelve science textbooks. In the seventh-grade science textbooks, there were 502 gender representations (20.3\%). It was 327 representations (15.7\%) for the sixth-grade science textbooks and was 308 representations (18.1\%) for the eighth-grade ones.

There were more female representations (167 images) than male ones (160) in the sixth-grade science textbooks especially the ones published in 2011 and 2017 involved more female representations than male representations (Figure 17).

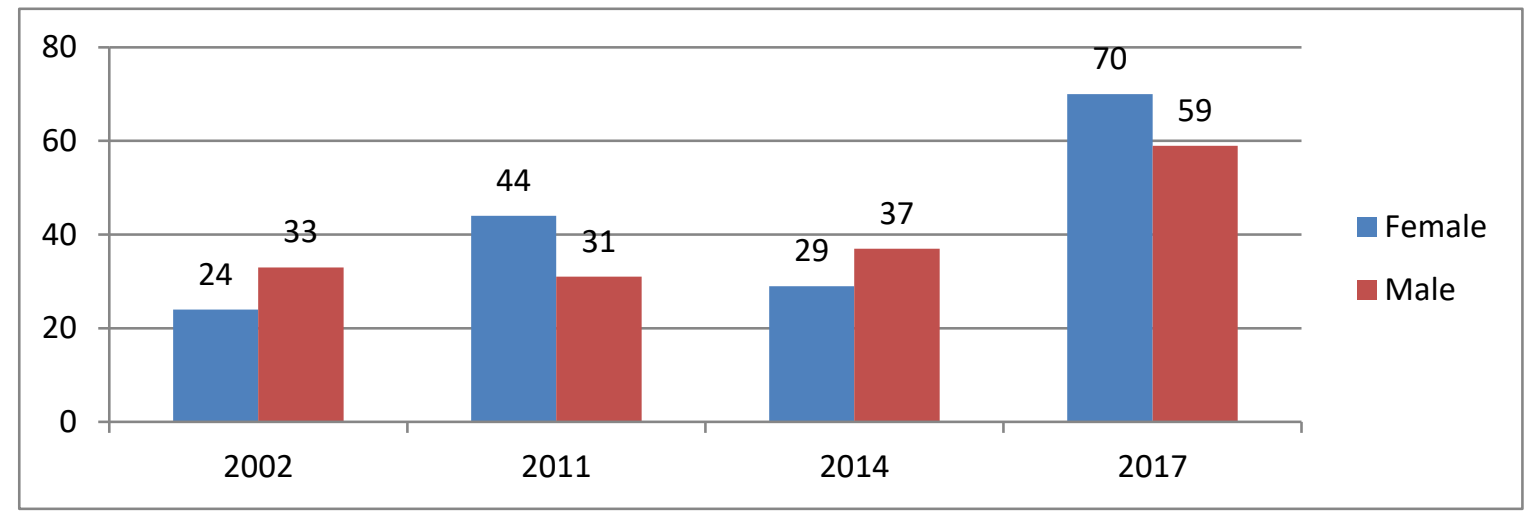

Figure 17. The sixth grade textbooks' analysis based on gender representations.

For the seventh-grade science textbooks, 304 male representations and 198 female representations included in all of the science textbooks. Only the textbooks published in 2017 involved more female representations than male ones (Figure 18). 


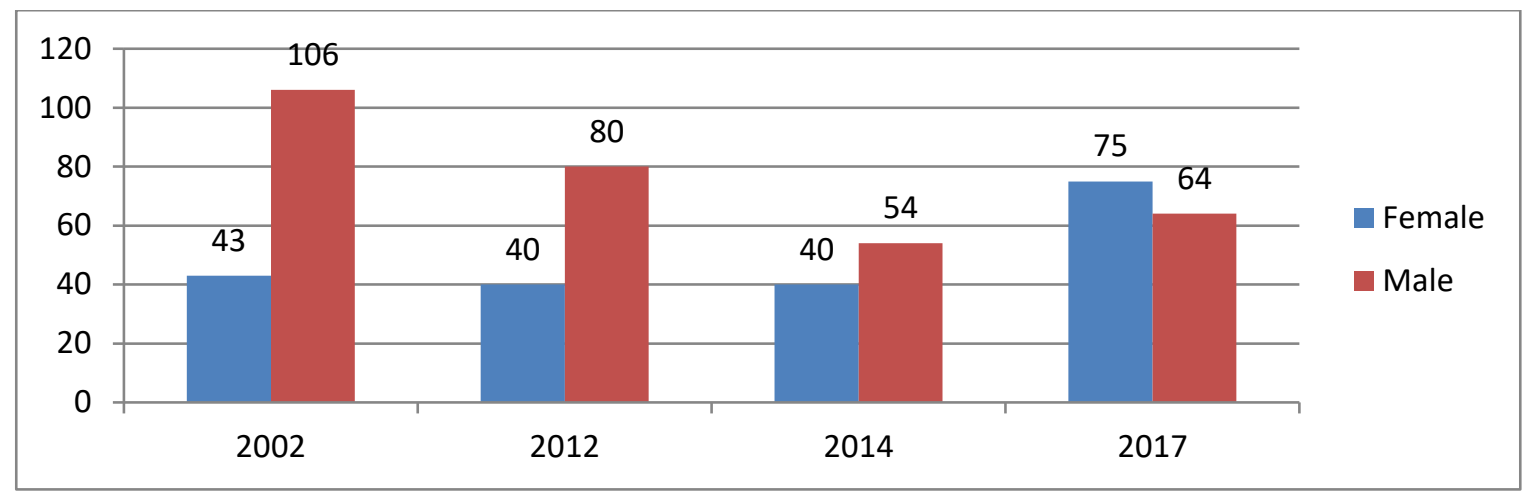

Figure 18. The seventh grade textbooks' analysis based on gender representations.

Similar findings were reached for eighth-grade science textbooks. There were more male representations (172 images) than female representations (136 images) in a total of the eighthgrade science textbooks. The textbook published in 2011 involved an equal number of male and female representations (Figure 19).

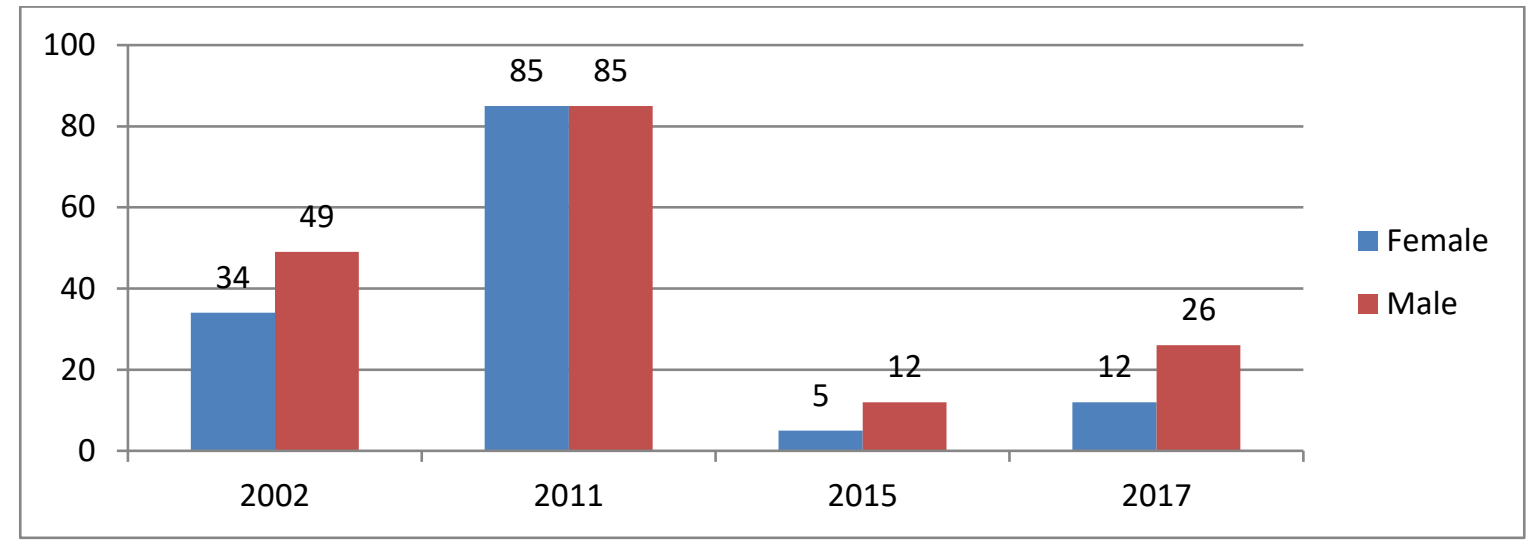

Figure 19. The eighth grade textbooks analysis based on gender representations.

\section{How did the degree of relationship between texts and images in middle school science textbooks change from 2002 to 2017 according to grade levels?}

It was reached that the representations in science textbooks mostly mentioned in the texts. The representations in the sixth-grade science textbooks had the highest ratio $(96.5 \%)$ (Figure 20). It was $93.4 \%$ for the seventh-grade science textbooks (Figure 21) and $87.8 \%$ for the eighth-grade science textbooks (Figure 22).

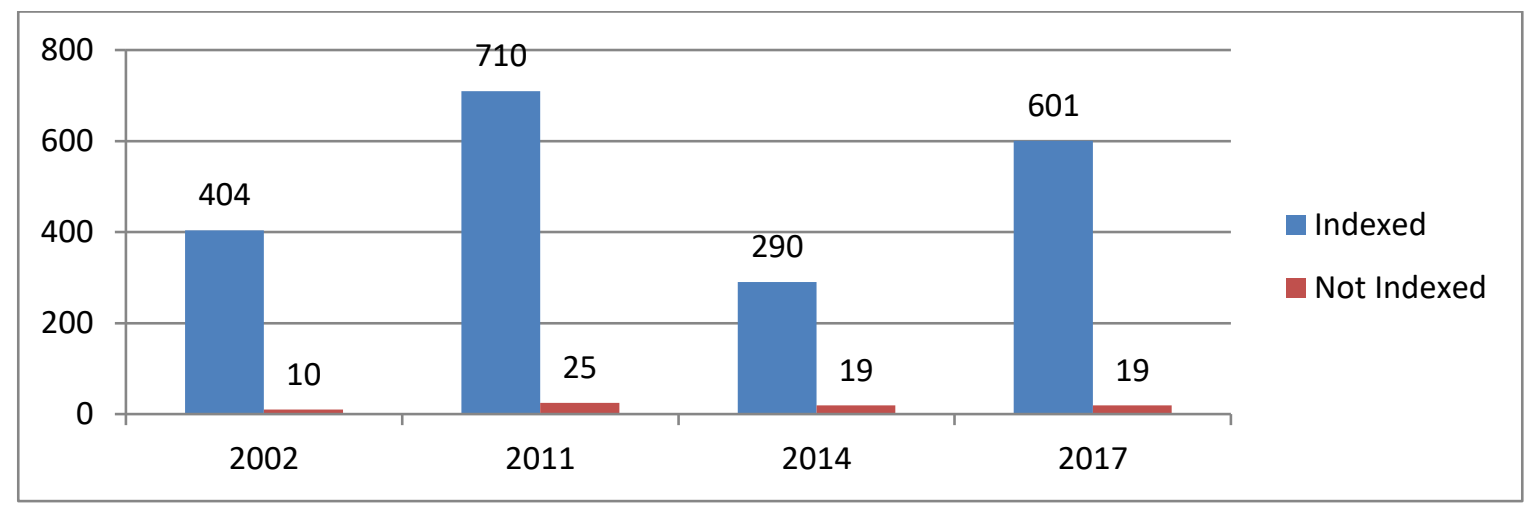

Figure 20. The sixth grade textbooks analysis based on indexing. 
Analysis of the sixth-grade science textbooks showed that almost all of the representations indexed in the main texts. The relatedness between texts and visuals were 97.6\%, 96.6\%, $93.9 \%$, and $96.9 \%$ concerning the publication years of the sixth grade science textbooks, respectively. A similar result was also found for the seventh-grade science textbooks. The indexing ratios were $95.5 \%, 89.4 \%, 94.9 \%$, and $92.1 \%$ with respect to the publication years of the seventh grade science textbooks, respectively.

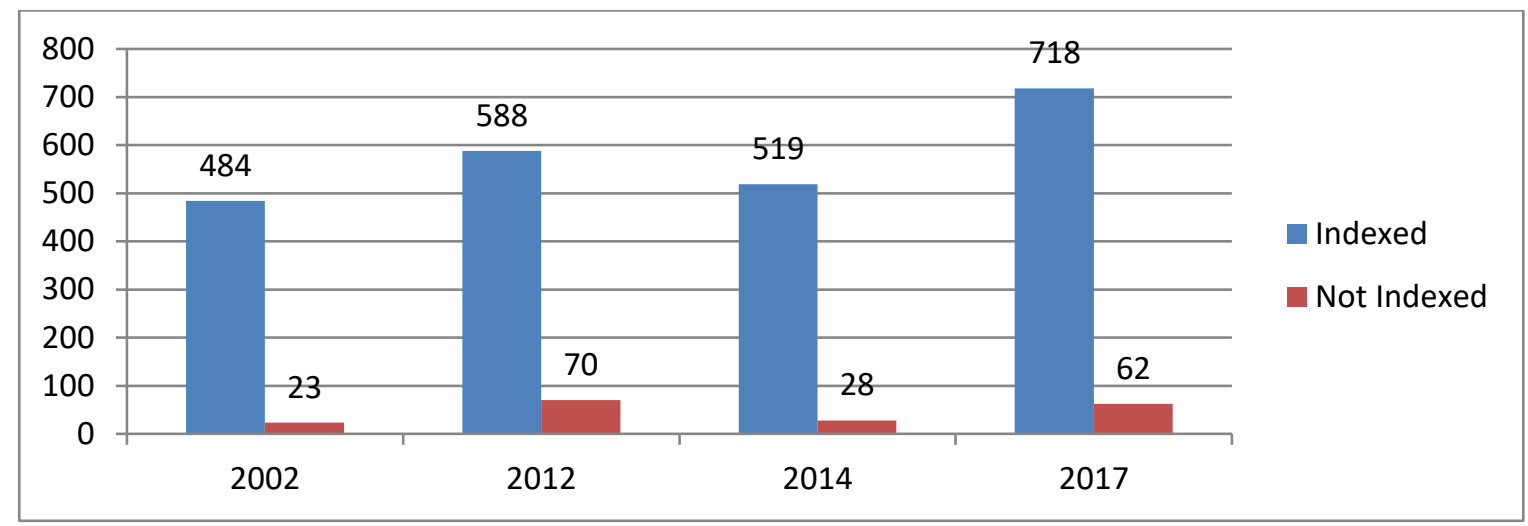

Figure 21. The seventh grade textbooks analysis based on indexing.

For the eighth-grade science textbooks, the one published in 2017 had the highest ratio $(96.5 \%)$. On the other side, $78.6 \%$ of the representations were indexed in the main texts for the textbook published in 2015, which was the lowest ratio in the total of four eighth grade science textbooks. Whereas it was $87.1 \%$ for the textbook published in 2002 , the ratio was $91.5 \%$ for the one published in 2011.

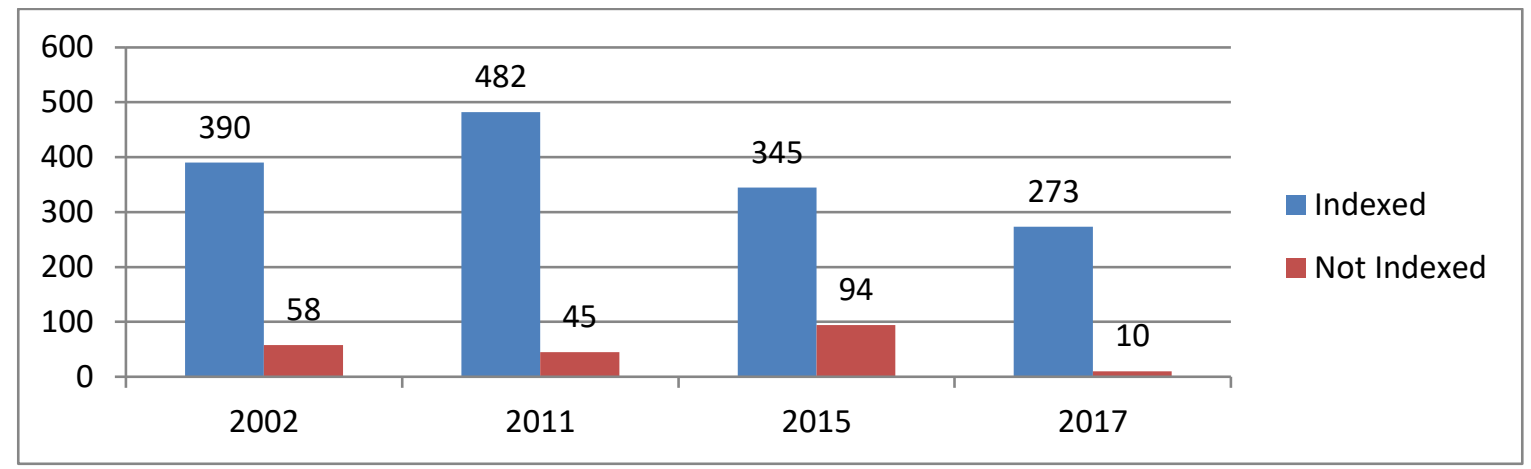

Figure 22. The eighth grade textbooks analysis based on indexing.

\section{How did the properties of the captions in the middle school science textbooks change from 2002 to 2017 according to the grade levels?}

The representations from all science textbooks were mainly problematic especially the ones in the seventh-grade science textbooks because only $18.8 \%$ of all representations in the seventh-grade textbooks had proper captions. For the sixth and eighth grade textbooks, less than half of the representations had suitable captions ( $46.5 \%$ and $47.5 \%$ respectively). Analysis of the sixth-grade textbooks based on captioning showed that textbooks published in 2017 had better representations in terms of captioning (Figure 23). Only 12.1\% of the visuals in the sixth grade science textbooks had proper captions. Whereas the ratio of the visuals with proper caption was $37 \%$ for the textbook published in 2011, the ratio decreased to $20.7 \%$ for the one published in 2014. 


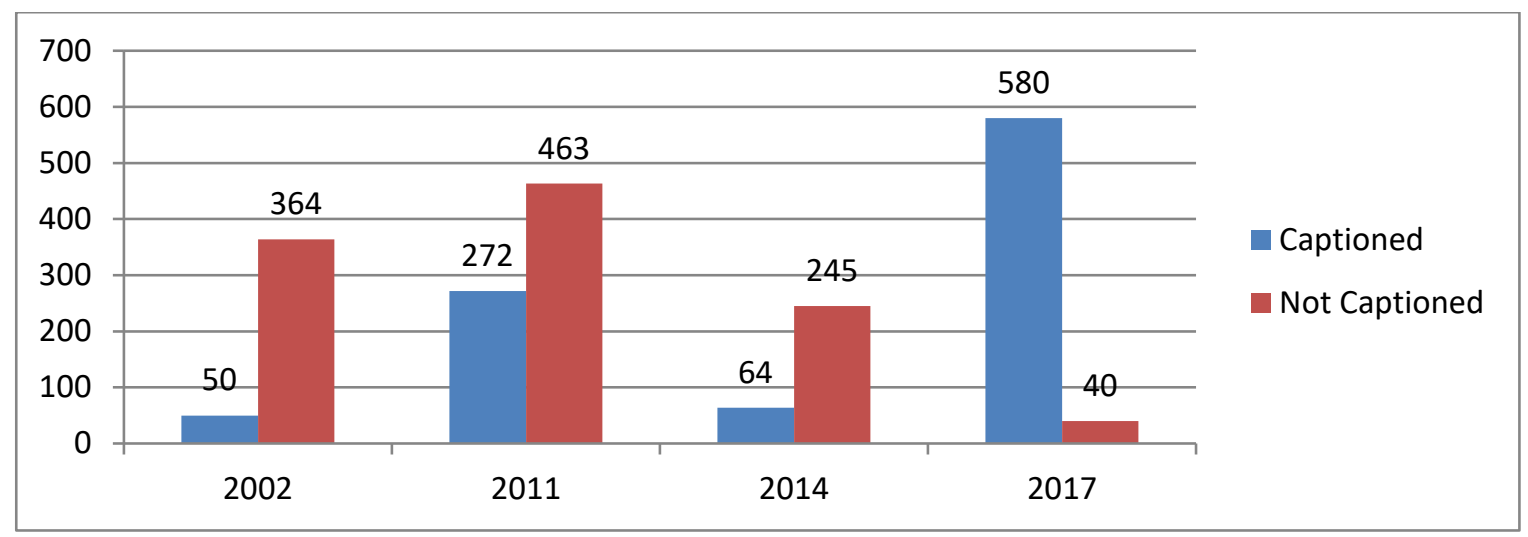

Figure 23. The sixth grade textbooks analysis based on captioning.

Approximately one-fifth of the representations (18.8\%) in seventh-grade textbooks had proper captions. It had the highest ratio for the textbooks published in $2014(26.0 \%)$ and had the lowest ratio for the ones published in 2002 (10.0\%) (Figure 24). The ratio for the visuals that have proper caption in the seventh grade science textbook published in 2012 was $16.9 \%$. In the recent textbook published in 2017 , the ratio was $21.2 \%$.

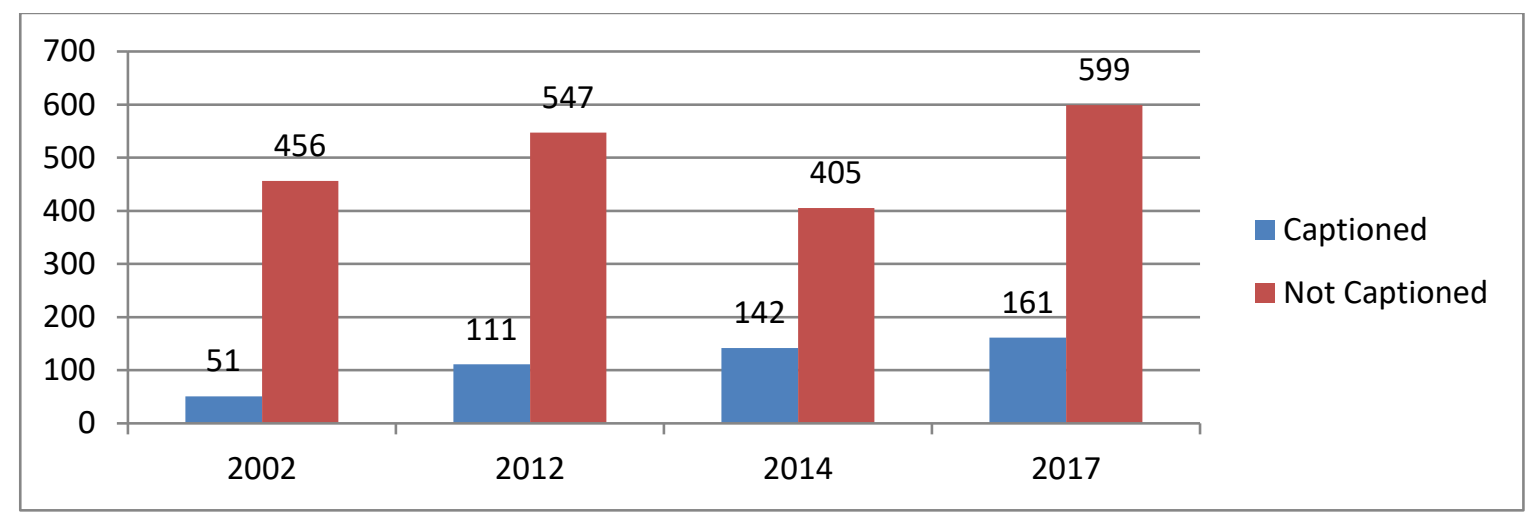

Figure 24. The seventh grade textbooks analysis based on captioning.

The representations in the recently published eighth-grade textbooks -the one published in 2017- had better results in terms of captioning. The ratios of representations with suitable captions increased from 13.6\% to $72.8 \%$ between 2002 and 2017 (Figure 25). Whereas the ratio was $52.6 \%$ for the eighth grade science textbook published in 2011, it was $59.9 \%$ for the one published in 2015.

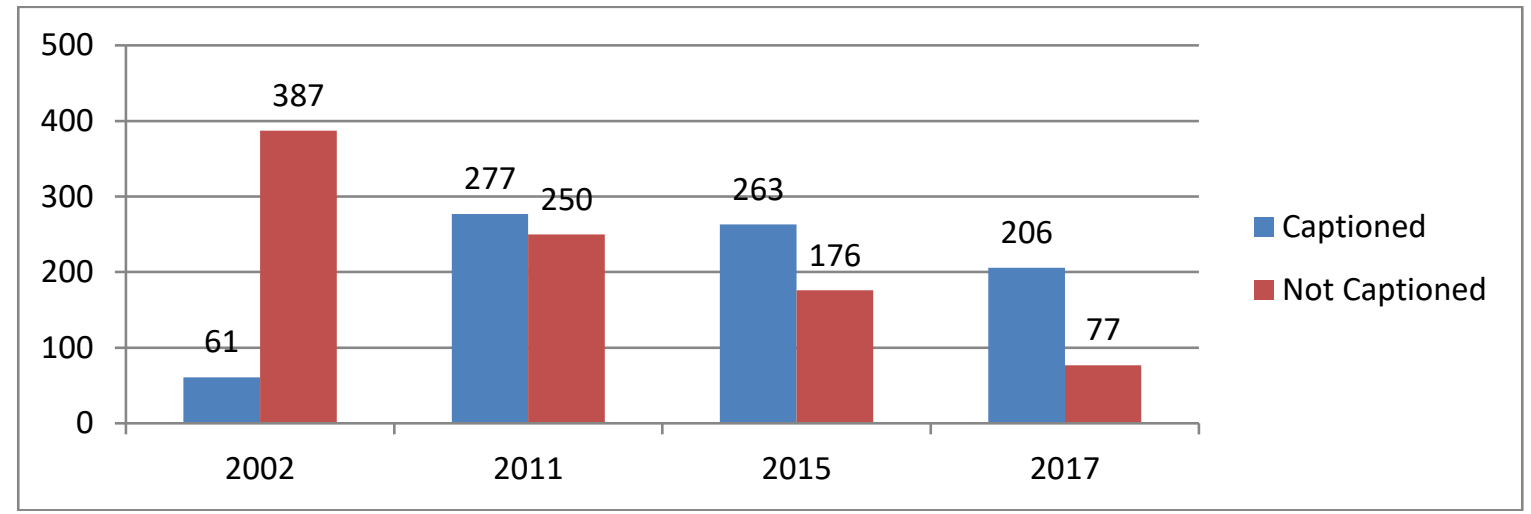

Figure 25. The eighth grade textbooks analysis based on captioning. 


\section{How did the functions of the visuals in middle school science textbooks change from 2002 to 2017 according to the grade levels?}

Realistic representations have been mainly used in middle school science textbooks. For the eighth-grade science textbooks, $64.3 \%$ of all representations were found as realistic. It was $55.3 \%$ for the sixth-grade science textbooks and $55.8 \%$ for the seventh-grade science textbooks. These data show that more than half of the representations from all science textbooks were realistic. Hybrid representations were at the lowest ratio. Furthermore, it was reached that about one-third of the representations (34.6\%) were found as conventional representations. Analysis of the sixth-grade textbooks based on the formality of visual images showed that the textbooks published in 2011 had more realistic images (66.2\%). The textbook published in 2017 had a similar ratio for both conventional and realistic representations (45.5\% and $49.3 \%$ respectively) (Figure 26 ).

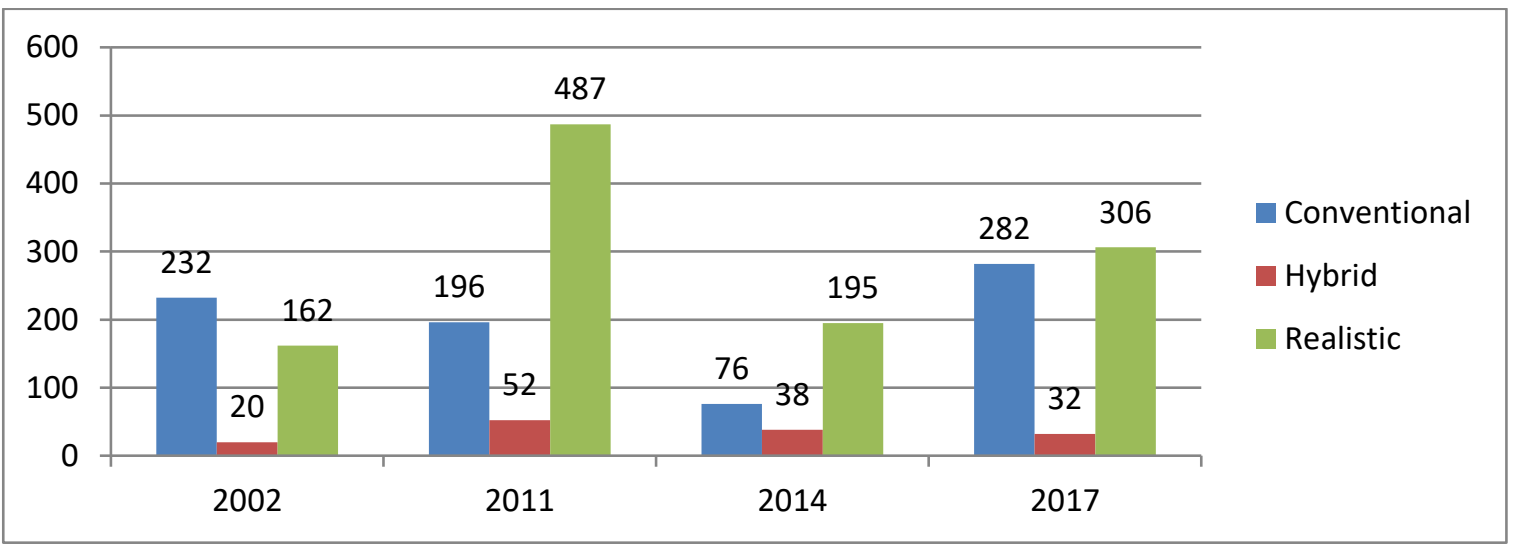

Figure 26. The sixth grade textbooks analysis based on the formality of visual image.

The findings based on examination of the representations in the seventh-grade textbooks showed that although realistic representations used commonly in all of the seventh-grade science textbooks, the hybrid representations (24.5\%) in the textbooks published in 2014 had a higher ratio than the conventional representations $(16.1 \%)$. On the other side, there were more conventional representations $(48.2 \%)$ than realistic $(45.6 \%)$ and hybrid representations $(6.2 \%)$ in the seven grade textbooks published in 2017 (Figure 27).

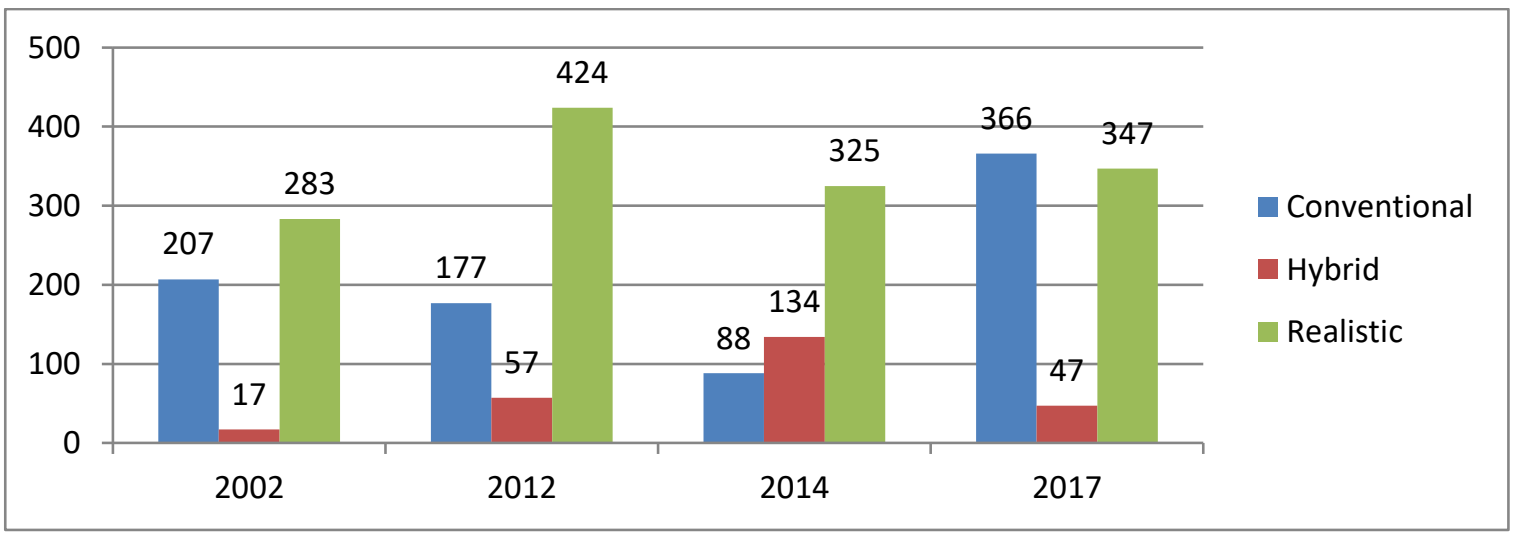

Figure 27. The seventh grade textbooks analysis based on the formality of visual image.

The results indicated that six of 10 representations were realistic in all of the eighth-grade science textbooks. The ratio of the conventional representations decreased from $46.9 \%$ to 
19.8\% from 2002 to 2017 . There were very limited hybrid representations in the eighth-grade science textbooks (Figure 28).

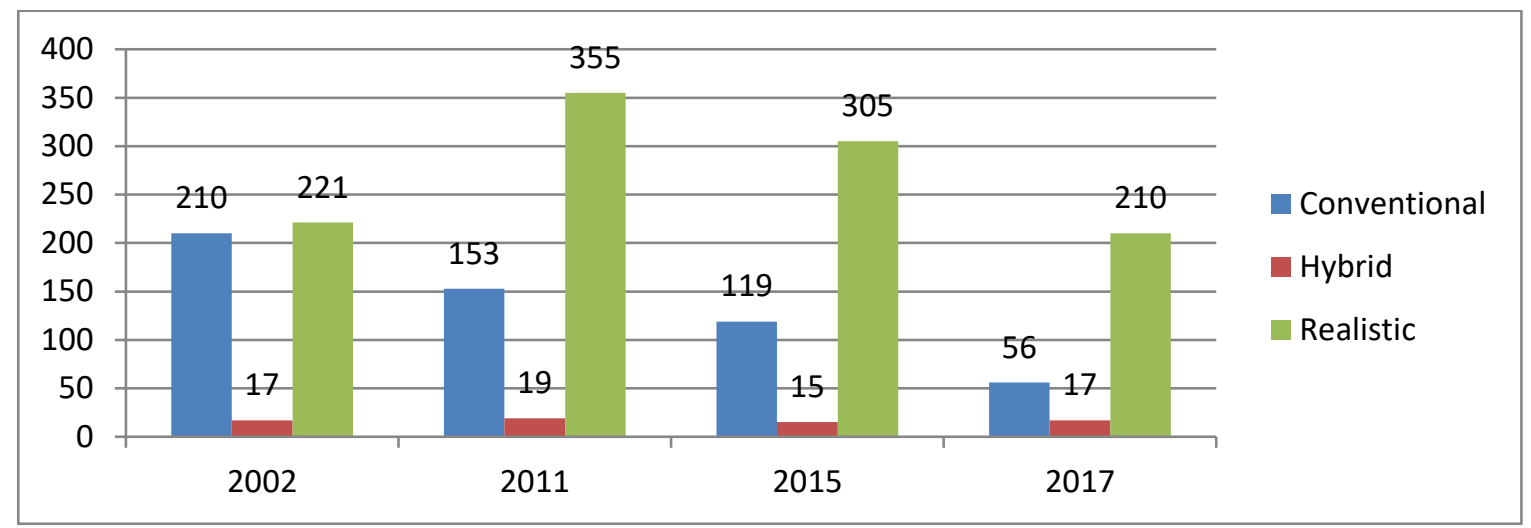

Figure 28. The eighth grade textbooks analysis based on the formality of visual image.

What were the functions of the visuals in middle school science textbooks from 2002 to 2017 with respect to the grade levels?

A total of 1036 representations fell into this category. A similar number of images involved in each grade of middle school (338 images from sixth-grade science textbooks, 387 images from seventh-grade science textbooks, 311 images from eighth-grade science textbooks). The findings revealed that analytical images were commonly used in middle school science textbooks. Whereas it had the highest ratio in the sixth-grade science textbooks $66.6 \%$ (225 images), it was the lowest for the eighth-grade science textbooks $(51.4 \%$; 160 images).

Figure 29 shows that narrative images were in the second rank with 61 images (18.0\%) and there were 27 classificational $(8.0 \%)$ and 25 metaphorical images $(7.4 \%)$ in the sixth-grade science textbooks.

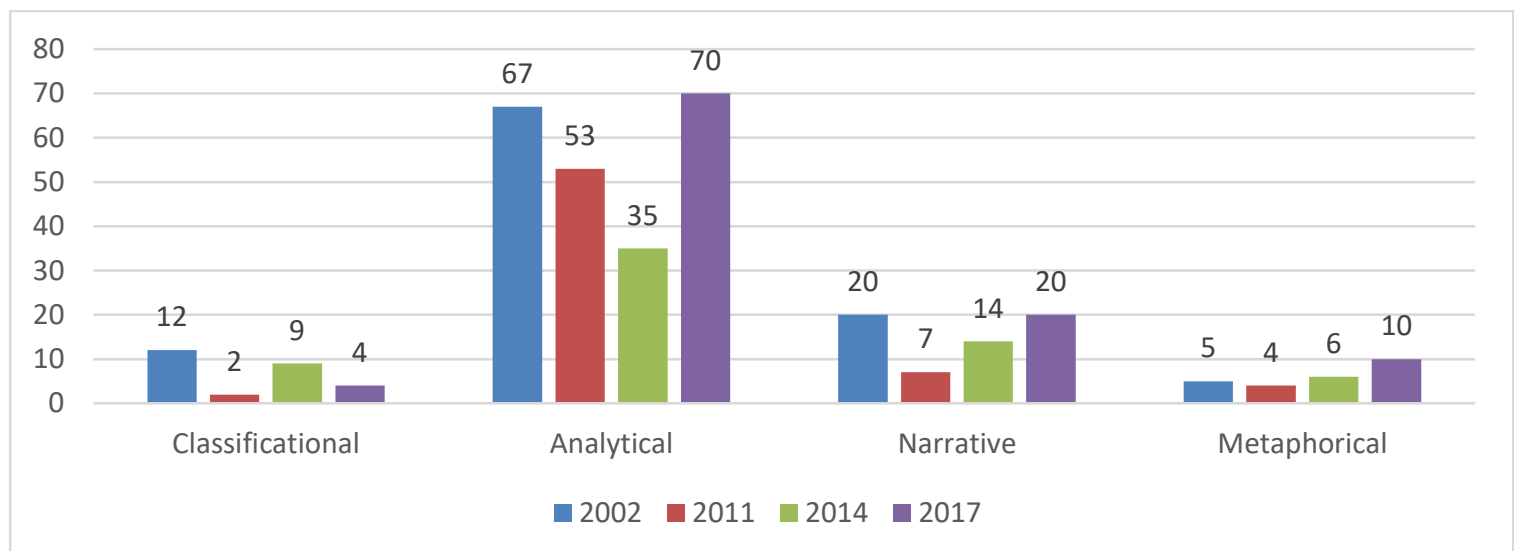

Figure 29. The sixth grade textbooks analysis based on the function of visual images.

In the seventh-grade science textbooks, Figure 30 indicates that $62.5 \%$ of images (242 images) in this category were analytical. Also, there were 72 narrative images (18.6\%), 43 classificational images $(11.1 \%)$, and 30 metaphorical images $(7.8 \%)$ in the seventh-grade science textbooks. 


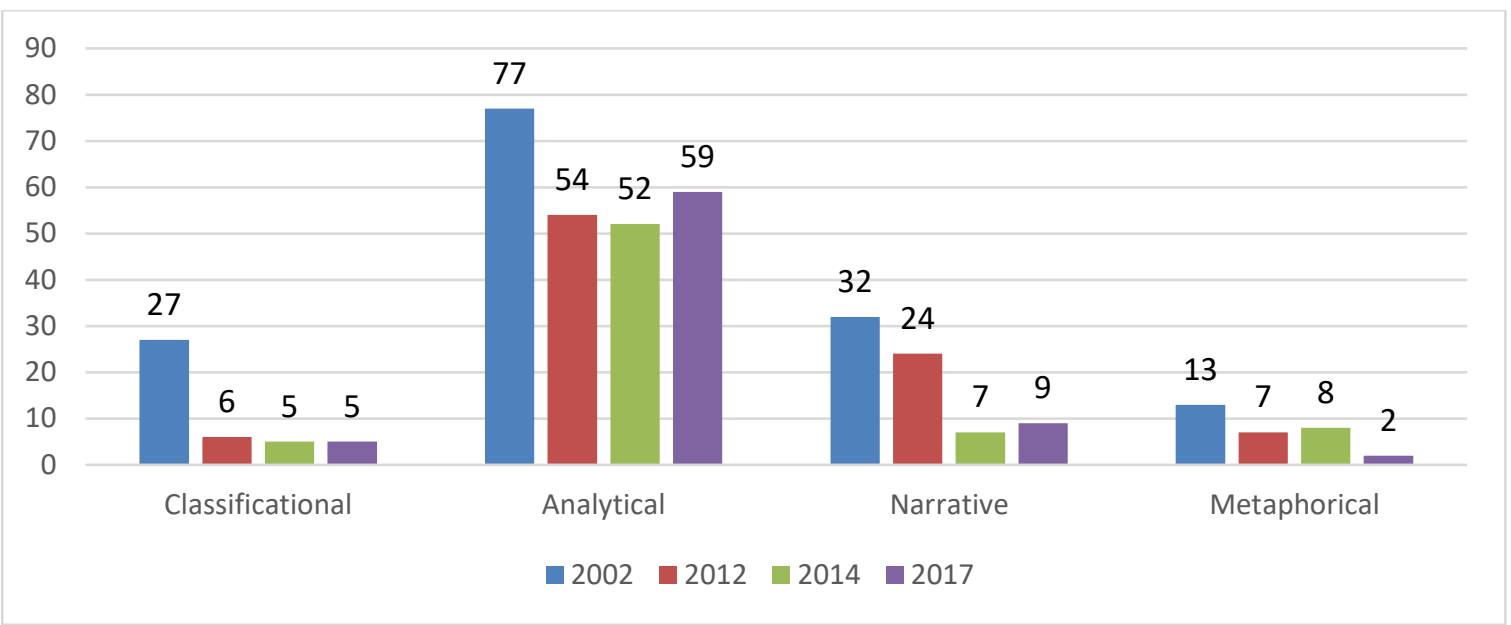

Figure 30. The seventh grade textbooks analysis based on the function of visual images.

Although the eighth-grade science textbooks had the lowest ratio for the analytical images, it was still more than half of the images in this category $(51.4 \% ; 160$ analytical images). Figure 31 shows that there were 88 narrative images (28.3\%), which was the highest ratio for the narrative ones in middle school science textbooks.

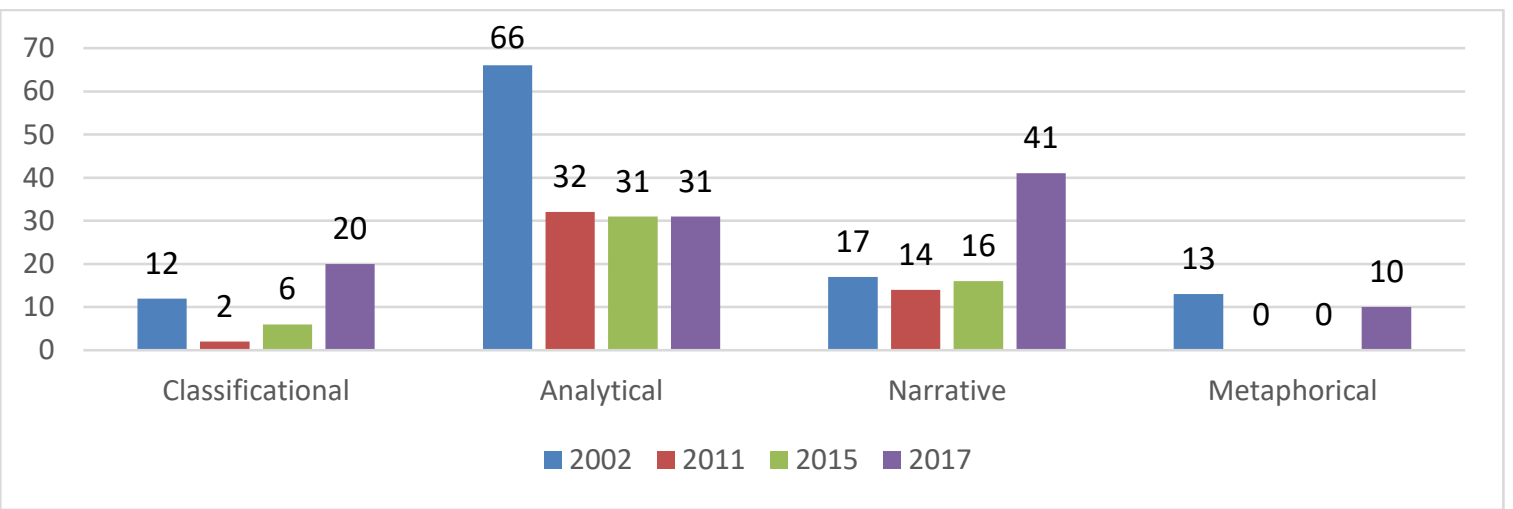

Figure 31. The eighth grade textbooks analysis based on the function of visual images.

On the other hand, in terms of classificational images, eighth-grade science textbooks had the highest ratio (12.9\%). Lastly, 23 metaphorical images (7.4\%) involved in eighth-grade science textbooks. It was an interesting finding that there were no metaphorical images in the eighthgrade science textbooks published in 2011 and 2015.

\section{Discussion}

In the current research, the images in the middle school science textbooks in terms of graphical types, gender representations, and relatedness to text, captioning, formality, and functions of visual images were examined. The results showed that iconic representations were mainly used in middle school science textbooks. This finding means that the topics in the middle school science textbooks are mainly taught by concrete images. Iconic representations are effective for students to know the structures and visual appearances of the concepts which can be seen by a naked eye (Khine \& Liu, 2017). They can be also used to attract students' attention (Harrison \& Treagust, 2003) for teaching a new concept (Johnstone, 2007). Yet, science education involves many abstract concepts and trying to teach such concepts with iconic representations may cause misconceptions for students. It would be reasonable if the number of iconic representations decreases concerning the increases in grade 
levels because eighth-grade middle school students' perceptions might be better to conceptualize the abstract concepts. Nonetheless, iconic representations have the highest ratio for seventh-grade science textbooks. Furthermore, the total number of images is at most for the seventh-grade science textbooks. The reason for these findings might be that the numbers of objectives in the science curriculum are the highest for this grade level. Schematic representations also have crucial roles in science teaching since they mostly represent the abstract concepts that are common in science education. It was unexpected finding that there was the lowest frequency for schematic representations in the eighth-grade science textbooks because it is usual that an increase in the grade level is parallel to the increase in understanding of abstract concepts (Kapici \& Savasci-Acikalin, 2015). Charts, graphs, and augmented reality were the lowest type of images used in the middle school science textbooks. Abstract concepts are too small to be seen by a naked eye, so they are mostly represented by schematic representations, graphs, and tables. The lower ratios of usage of these representations mean that middle school science textbooks mainly didn't involve images of these types of concepts. This can be assumed as a big handicap for students because not understanding the meaning of such representations makes difficult to understand abstract concepts or ideas (Taber, 2009). Lastly, there were minimum representations about the type of augmented reality, which are produced by using computer technology. The nature of abstract concepts can be visible through computer technology, so using much more augmented reality images in middle school science textbooks might be beneficial for students.

In terms of gender representations, there were more male representations than girl representations in the middle school science textbooks except for the sixth-grade science textbooks. Textbooks are important sources to teach children about their roles based on their gender (Brownlow \& Durham, 1997). There are many more studies in the related literature (e.g., Kerkhoven et al., 2016) which concluded that male representations were used much more than female representations. The reason for this conclusion might be that there are many more men who are interested in workforce-related with science fields than women (UNESCO, 2018). In order to encourage women to join for working in science-related areas, one of the efficient ways can be to include their views and ideas (European Commission Ethics and Gender, 2012), especially in science textbooks. There should be a balance about the distribution of gender representations in science textbooks which might have an impact on showing men and women can do science.

For the relatedness to text criteria, most of the visuals were mentioned in the main text in the middle school science textbooks. This is also an important outcome of the research because exposing learners' cognitive systems with two different and complementary stimuli can enable them to learn meaningfully and deeply. Main texts are primary sources for students to interpret the images (Pozzer Ardenghi \& Roth, 2004). It might be difficult for learners to understand the images properly if there is no link or relation within the text.

Captioning is also one of the important properties of images to inform the learner what the image is about (Pozzer \& Roth, 2003). Yet, the findings showed that the images were the most problematic in terms of captions. It was seriously problematic for the representations in the seventh-grade science textbooks because there were only one out of five images had a proper caption. It might be difficult for middle school students to understand what the image aims to teach without a proper caption.

For the criteria about the formality of the visual images, the findings were coherent with the ones about the graphical types of representations because more than half of the images in each 
grade level's (6th, 7th, and 8th) science textbooks were realistic. Although the definitions of iconic representations and realistic images are similar, there are some differences between the numbers of the images. The source of this difference might be due to the structure of the rubric because whereas the graphical types were examined under four categories (iconic, schematic, charts/graphs, augmented), formality of the visual images were evaluated under three categories (conventional, hybrid, realistic). Dimopoulos et al. (2003) also reached that the visuals in the science textbooks and science press are rich in terms of the physical appearances of the things or concepts. Another finding was that one out of three images were conventional images in the science textbooks which was another result similar to schematic representations. Lastly, hybrid representations, which involve the combination of realistic and conventional representations, had the lowest ratio. This kind of representation is also a powerful tool for teaching because students can see concrete and abstract forms of the concepts, so it would be better to understand easily.

The last category was the functions of the visual images in the middle school science textbooks. It was reached that analytical images were commonly used in the science textbooks. This shows that the images had connections with the text or have surface labels. The main difference between a surface label and caption is that whereas surface label introduces the specific part of the image, caption identifies the mission of the images (Kapici \& Savasci-Acikalin, 2015). In terms of pedagogical function, the better option is including both of them. Narrative, classificational and metaphorical images were used at very low levels in the science textbooks. This is also a big deficiency for the textbooks. This finding shows that there were limited images in the science textbooks to represent process-related topics (i.e., vector direction), technical issues (i.e., the procedure of an experiment) and cultural symbols.

As mentioned in the literature (i.e. Anagnostopoulou et al., 2012; Hatzinikita et al., 2008), textbooks can be an important factor in students' scores in the (inter)national tests because textbooks are major sources of information for both teachers and students in Turkey. Since involving much more concrete images in the textbooks, students may have trouble interpreting the abstract concepts. Although there are limited graphs and tables in the textbooks, there are a lot of question items, which requires analyzing graphs and tables, in the (inter)national tests. The results of international exams such as PISA and TIMMS support the view presented in the current research.

\section{Conclusion}

All in all, there are abundant representations in Turkish middle school science textbooks. Yet, they mostly focus on real copies of objects or concepts. Although there are many topics, which involve abstract concepts, in science education, there are limited representations for those objects or concepts. Furthermore, there are rarely multiple representations in which students can see different representation levels (i.e., macroscopic, sub-microscopic, symbolic) together. It might be better for learners to observe different representation levels together. For example, a molecular structure of water can be represented with its chemical formula $\mathrm{H}_{2} \mathrm{O}$. In this way, a learner might realize that whereas the two same molecules represent the $\mathrm{H}$ atoms, the unique molecule stands for the $\mathrm{O}$ atom.

Most of the representations have connections with the texts. This is a good conclusion because the text and the representation complement each other and stimulate different parts of working memory that are important for learning. The problematic issue is the captions for the 
representations. Captions can be assumed as an identity of a representation. It is possible to misunderstand what the representation aims to teach if it has no caption. The representations in Turkish middle school science textbooks mainly had a problem in terms of captioning.

Gender representations in the textbooks are also important. It may have an impact on the status of a woman in society. The female representations have a disadvantage in terms of their numbers in the Turkish middle school science textbooks. Gender equity should be supplied in the textbooks. Females should be represented as engineers, scientists, software developer and technical workers in the textbooks. They should realize that they can work in science-related jobs as much as the male.

The formality of visual representations also showed that most of the representations are realistic in the textbooks. It is a compatible finding with the one which showed the representations are mostly real copies of objects/concepts. The functionality of visual representations showed that the visuals in the textbooks mostly represent the part-whole structure of the concepts. It is a powerful kind of visual representations in terms of educational context.

\section{Acknowledgment}

Thanks a lot to the MoNE and Tuna publishers for allowing us to use some example illustrations from the middle school science textbooks published by them.

Part of this paper was presented at the International Conference on Education in Mathematics, Science and Technology (ICEMST) on April 28 - May 1, 2018, in Marmaris, Turkey, and was published in the conference proceeding book.

\section{References}

Abd-El-Khalick, F., Myers, J. Y., Summers, R., Brunner, J., Waight, N., Wahbeh, N., Zeineddin, A. A., \& Belarmino, J. (2017). A longitudinal analysis of the extent and manner of representations of nature of science in US high school biology and physics textbooks. Journal of Research in Science Teaching, 54(1), 82-120.

Ahtineva, A. (2005). Textbook analysis in the service of chemistry teaching. Universitas Scientiarum, 10, 25-33.

Ainsworth, S. (1999). The functions of multiple representations. Computer \& Education, 33, 131-152.

Ainsworth, S. (2006). DeFT: A conceptual framework for considering learning with multiple representations. Learning and Instruction, 16(3), 183-198.

Anagnostopoulou, K., Hatzinikita, V., \& Chritidou, V. (2012). PISA and biology school textbooks: The role of visual material. Procedia-Social and Behavioral Sciences, 46, $1839-1845$.

Baddeley, A. (1992). Working memory. Science, 255(5044), 556-559.

Banilower, E. R., Smith, P. S., Wiess, I. R., Malzahn, K. A., Campbell, K. M., \& Weiss, A. M. (2012). Report of the 2012 national survey of science and mathematics education. Chapel Hill, NC: Horizon Research Inc.

Bransford, J. D., Brown, A. L., \& Cocking, R. C. (2000). How people learn: Brain, mind, experiences, and school. Washington, DC: National Academy Press.

Brownlow, S., \& Durham, S. (1997). Sex differences in the use of science and technology in children's cartoons. Journal of Research in Science Teaching, 6(2), 103-110. 
Cheng, M. M. W., \& Gilbert, J. K. (2014). Students' visualization of metallic bonding and the malleability of metals. International Journal of Science Education, 36(8), 1373-1407.

Chiappetta, E. L., \& Fillman, D. A. (2007). Analysis of five high school biology textbooks used in the United States for inclusion of the nature of science. International Journal of Science Education, 29(15), 1874-1868.

Chittleborough, G., Treagust, D., \& Mocerino, M. (2005). Non-major chemistry students' learning strategies: Explaining their choice and examining the implications for teaching and learning. Science Education International, 16(1), 5-21.

Çelik Koyuncu, A., Tiryaki, N., Kavas, B., \& Salmaner, V. (2002). Eighth grade science textbook. Ankara: Ministry of National Education Press.

Demirdöğen, B. (2017). Examination of chemical representations in Turkish high school chemistry textbooks. Journal of Baltic Science Education, 16(4), 472-499.

Devetak, I., \& Vogrine, J. (2013). The criteria for evaluating the quality of the science textbooks. In M. S. Khine (Ed.), Critical analysis of science textbooks (pp. 3-15). Dordrecht: Springer.

Dimopoulos, K., Koulaidis, V., \& Sklaveniti, S. (2003). Towards an analysis of visual images in school science textbooks and press articles about science and technology. Research in Science Education, 33(2), 189-2016.

European Commission Ethics and Gender. (2012). She figures 2012: Gender in research and innovation. Retrieved from https://ec.europa.eu/research/sciencesociety/document_library/pdf_06/she-figures-2012_en.pdf

Gabel, D. L. (1993). Use of the particulate nature of matter in developing conceptual understanding. Journal of Chemical Education, 70(3), 193-194.

Geske, A., \& Geske, R. (2010, July). Content of textbooks: One of the factors affecting fourthgrader science achievements in TIMMS. Paper presented at the 4th IEA International Research Conference, Gothenburg, Sweden.

Gkitzia, V., Salta, K., \& Tzougraki, C. (2011). Development and application of suitable criteria for the evaluation of chemical representations in school textbooks. Chemistry Education Research and Practice, 12(1), 5-14.

Güngör, B., Dökme, İ., Ülker, S., Yıldıran, F. N., Aydınlı, R., \& Baş, B. (2002). Sixth grade science textbook]. Ankara: Ministry of National Education Press.

Harrison, A. G., \& Treagust, D. F. (2003). The particulate nature of matter: Challenges in understanding the submicroscopic world." In J. K. Gilbert, O. De Jong, R. Justi, D. F. Treagust, \& J. H. Van Driel (Eds.), Chemical education: Towards research-based practice (pp. 189-212). Dordrecht: Kluwer Academic Publishers.

Hatzinikita, V., Dimopoulos, K., \& Christidou, V. (2008). PISA test items and school textbooks related to science: A textual comparison. Science Education, 92(4), 664687.

Hegarty, M., Carpenter, P. A., \& Just, M. A. (1991). Diagrams in the comprehension of scientific texts.” In R. Barr, M. L. Kamil, P. Mosenthal, \& P. D. Pearson (Eds.), Handbook of reading research (pp. 641-668). New York: Longman.

Ilhan, G. O., Seker, M,. \& Kapici, H. O. (2015). Examination of tourism concept in fifth grade social studies textbooks. International Journal of Field Education, 1(1), 42-62.

Johnstone, A. H. (1993). The development of chemistry teaching: A changing response to changing demand. Journal of Chemical Education, 70(9), 701-705.

Johnstone, A. H. (2007). Science education: We know the answers, let's look at the problems. Proceedings of the $5^{\text {th }}$ Greek Conference Science Education and New Technologies in Education, 1, 1-11. 
Kapıc1, H. O., \& Savasci-Acıkalın, F. (2015). Examination of visuals about particulate nature of matter in Turkish middle school science textbooks. Chemistry Education Research and Practice, 16(3), 518-536.

Kerkhoven, A. H., Russo, P., Land-Zandstra, A., Saxena, A., \& Rodenburg, F. J. (2016). Gender stereotypes in science education resources: A visual content analysis. PloS One, 11(11), 1-13.

Kesidou, S., \& Roseman, J. E. (2002). How well do middle school science programs measure Up? Findings from project 2061's curriculum review. Journal of Research in Science Teaching, 39(6), 522-549.

Khine, M. S., \& Liu, Y. (2017). Descriptive analysis of the graphic representations of science textbooks. European Journal of STEM Education, 2(3), 1-15.

Kılıç, M. S., \& Sert, H. (2015). Primary school $5^{\text {th }}$ grade science and technology lesson book's investigation of multiple intelligence theory. Procedia-Social and Behavioral Sciences, 174, 2577-2581.

Lee, V. R. (2010). Adaptations and continuities in the use and design of visual representations in US middle school science textbooks. International Journal of Science Education, 32(8), 1099-1126.

Liu, Y., \& Khine, M. S. (2016). Content analysis of the diagrammatic representations of primary science textbooks. Eurasia Journal of Mathematics, Science \& Technology Education, 12(8), 1937-1951.

Mayer, R. E. (1993). Illustrations that instruct. In R. Glaser (Ed.), Advances in instructional psychology, (pp. 253-284). Hillsdale, New Jersey: Lawrence Erlbaum Associates.

Mayer, R. E. (1997). Multimedia learning: Are we asking the right questions? Educational Psychologist, 32(1), 1-19.

Mayer, R. E. (1999). Multimedia aids to problem-solving transfer. International Journal of Educational Research, 31, 611-623.

Mayer, R. E. (2003). The promise of multimedia learning: Using the same instructional design methods across different media. Learning and Instruction, 13, 125-139.

Mullis, I. V., Martin, M. O., Foy, P., \& Drucker, K. T. (2012). TIMMS 2011international results in reading. Amsterdam: TIMMS International Association for the Evaluation of Educational Achievement.

Nakiboğlu, C. (2009). Examination on expert chemistry teachers' secondary school chemistry textbook usage. Journal of Ahi Evran University Kırşehir Faculty of Education, 10(1), $1-10$.

Nyachwaya, J. M., \& Wood, N. B. (2014). Evaluation of chemical representations in physical chemistry textbooks. Chemistry Education Research and Practice, 15, 720-728.

Opfermann, M., Schmeck, A., \& Fischer, H. E. (2017). Multiple representations in physics and science education-Why should we use them?" In D. F. Treaguts, R. Duit, and H. E. Fischer (Eds.), Multiple representations in physics education (pp. 1-22). Cham, Switzerland: Springer.

Paivio, A. (1986). Mental representations: A dual coding approach. New York: Oxford Science Publications.

Papageorgiou, G., Amariotakis, V., \& Spiliotopoulou, V. (2017). Visual representations of microcosm in textbooks of chemistry: Constructing a systematic network for their main conceptual framework. Chemistry Education Research and Practice, 18, 559571.

Pinto, R., \& Ametller, J. (2002). Students' difficulties in reading images. Comparing results from four national research groups. International Journal of Science Education, 24(3), 333-341. 
Postigo, Y., \& López-Manjón, A. (2019). Images in biology: Are instructional criteria used in textbook image design? International Journal of Science Education, 41(2), 210-229.

Pozzer Ardenghi, L., \& Roth, W. (2004, April). Students' interpretation of photographs in high school biology textbooks. Paper presented at the annual meeting of the National Association for Research in Science Teaching, Vancouver, CA.

Pozzer, L. L., \& Roth, W. (2003). Prevalence, function and structure of photographs in high school biology textbooks. Journal of Research in Science Teaching, 40(10), 10891114.

Shehab, S. S., \& BouJaoude, S. (2017). Analysis of the chemical representations in secondary Lebanese chemistry textbooks. International Journal of Science and Mathematics Education, 15(5), 797-816.

Slough, S. W., McTigue, E. M., Kim, S., \& Jennings, S. K. (2010). Science textbooks' use of graphical representation: A descriptive analysis of four sixth grade science texts. Reading Psychology, 31(3), 301-325.

Taber, K. S. (2009). Learning at the symbolic level. In J. K. Gilbert, \& D. F. Treagust (Eds.), Models and modelling in science education: Multiple representations in chemical education (pp. 75-109). Netherlands: Springer.

Taş, U. E., Arıcı, Ö., Ozarkan, H. B., \& Özgürlük, B. (2016). National report of PISA 2015. Ankara, Turkey: Ministry of National Education.

Tsui, C.-C., \& Treagust, D. F. (2013). Introduction to multiple representations: Their importance in biology and biological education. In D. F. Treagust, \& C.-Y. Tsui (Eds.), Multiple representations in biological education (pp. 3-18). Dordrecht: Springer.

Tuncel, E. (2017). Seventh grade science textbook. Ankara: Tuna Publishing.

UNESCO. (2018). Women in science. Retrieved from http://uis.unesco.org/sites/default/files/documents/fs51-women-in-science-2018-en.pdf

Upahi, J. E., \& Ramnarain, U. (2019). Representations of chemical phenomena in secondary school chemistry textbooks. Chemistry Education Research and Practice, 20, 146159.

van den Ham, A.-K., \& Heinze, A. (2018). Does the textbook matter? Longitudinal effects of textbook choice on primary school students' achievement in Mathematics? Studies in Educational Evaluation, 59, 133-140.

van der Meij, J., \& de Jong, T. (2006). Supporting students' learning with multiple representations in a dynamic simulation-based learning environment. Learning and Instruction, 16, 199-212.

Yeh, Y-F. Y., \& McTigue, E. M. (2009). The frequency, variation, and function of graphical representations within standardized state science tests. School Science and Mathematics, 109(8), 435-449.

Yıldırım, A., Özgürlük, B., Parlak, B., Gönen, E., \& Polat, M. (2016). Pre-report of TIMMS 2015 national mathematics and science $4^{\text {th }}$ and $8^{\text {th }}$ grades. Ankara, Turkey: Ministry of National Education.

Wittrock, M. C. (1989. Generative processes of comprehension. Educational Psychologist, 24(4), 345-376. 


\section{Appendix A}

\begin{tabular}{|c|c|c|c|}
\hline Author (Publication year) & Grade & Publisher & Program \\
\hline $\begin{array}{l}\text { Güngör, B., Dökme, İ., Ülker, S., Yıldıran, } \\
\text { F.N., Aydınlı, R. \& Baş, B. (2002) }\end{array}$ & 6 & $\begin{array}{l}\text { MEB Publishing } \\
\text { [Ministry of National } \\
\text { Education] }\end{array}$ & 2000 \\
\hline $\begin{array}{l}\text { Büyük, Ş., Salmaner, V., Baş, Z. B. \& } \\
\text { Görür, N. (2002) }\end{array}$ & 7 & $\begin{array}{l}\text { MEB Publishing } \\
\text { [Ministry of National } \\
\text { Education] }\end{array}$ & \\
\hline $\begin{array}{l}\text { Çelik Koyuncu, A., Tiryaki, N., Kavas, B. } \\
\text { \& Salmaner, V. (2002) }\end{array}$ & 8 & $\begin{array}{l}\text { MEB Publishing } \\
\text { [Ministry of National } \\
\text { Education] }\end{array}$ & \\
\hline Taşar, M. F. (Ed.) (2011) & 6 & $\begin{array}{l}\text { MEB Publishing } \\
\text { [Ministry of National } \\
\text { Education] }\end{array}$ & 2004 \\
\hline Boyraz Topaloğlu, Ş. (2012) & 7 & Ekoyay Publishing & \\
\hline $\begin{array}{l}\text { Tunç, T., Bakar, E., Başdağ, G., İpek, İ., } \\
\text { Bağc1, N., Köroğlu, G. N., Yörük, N., \& } \\
\text { Keleş, Ö. (2011) }\end{array}$ & 8 & $\begin{array}{l}\text { MEB Publishing } \\
\text { [Ministry of National } \\
\text { Education] }\end{array}$ & \\
\hline Öcal, C. (2014) & 6 & Fenbil Publishing & 2013 \\
\hline Leblebicioğlu, G. (Ed.). (2014) & 7 & $\begin{array}{l}\text { MEB Publishing } \\
\text { [Ministry of National } \\
\text { Education] }\end{array}$ & \\
\hline Erbaş, K. (2015) & 8 & Tuna Publishing & \\
\hline Gökçe, N., \& Işık, N. (2017) & 6 & Tuna Publishing & 2017 \\
\hline Tuncel, E. (2017) & 7 & Tuna Publishing & \\
\hline Ataş, A. (2017) & 8 & Öğün Publishing & \\
\hline
\end{tabular}

